Review Article

\title{
An Overview of Nanostructured Li-based Thin Film Micro-batteries
}

\author{
ANGALAKURTHI RAMBABU ${ }^{1,2, *}$, SALURU B KRUPANIDHI ${ }^{2}$ and PRABEER BARPANDA ${ }^{1}$ \\ ${ }^{1}$ Faraday Materials Laboratory, Materials Research Centre, Indian Institute of Science, C.V. Raman \\ Avenue, Bangalore 560 012, India \\ ${ }^{2}$ Quantum Structures and Device Laboratory, Materials Research Centre, Indian Institute of Science, \\ C.V. Raman Avenue, Bangalore 560 012, India
}

(Received on 20 April 2018; Revised on 09 May 2018; Accepted on 31 July 2018)

\begin{abstract}
Li-ion batteries have ushered the portable electronics revolution empowering myriads of consumer electronic devices. The bulk Li-ion batteries using liquid organic electrolytes have gone through unprecedented commercial success. In parallel, allsolid-state thin film micro-batteries, employing solid electrolytes, have attracted much interest due to their potential applicationin microelectronic devices. Replacing the liquid electrolytes via solid electrolytes, operational safety can be enhanced while preserving the electrochemical performance. In this spirit, thin films of cathodes, anodes and solid electrolytes can be assembled to fabricate multilayered all-solid-state micro-batteries. The success of this niche sector largely depends on the development and assembly of key electrode and solid electrolyte components. The current review explores a gamut of cathodes, anodes and solid electrolytes for their potential application in all-solid-state thin filmmicro-batteries.
\end{abstract}

Keywords: All-solid-state Micro-batteries; Thin Films; Cathodes; Anodes; Solid Electrolytes

\section{Introduction}

'Energy' has emerged as the principal concern in the $21^{\text {st }}$ century with predicted global energy consumption crossing over 30 Terawatt by 2050 . Energy shortage and environmental pollution have become a global concern facing the world today. There is an urgent need to develop sustainable renewable energy generation to reduce fossil fuel consumption and efficient round-the-clock energy storage. Energy storage can be most practically realized by electrochemical storage technologies using reversible conversion of chemical to electrical energy. In this sector, lithium-ion batteries (LIBs) rule the roost owing to their light weight, high gravimetric/volumetric energy density, high power densityalong with long cycle life (Kuwata, 2006; Takada, 2013).No doubt, they are ubiquitous these days,propelling variety of consumer electronic devices and (hybrid) electric vehicles. On the other hand, recent developments in redox flow batteries have become prominent for large scale storage applications as they offer the high-power rate, long energy storage time and excellent response time with the ability to get full power in few seconds. These unique characteristics are really helpful to replace the LIBs, especially for large scale application (Ravikumar, 2017). However, the usage of flammable organic electrolytes in these LIBs can lead to thermal runaway and explosion during overcharging or short circuiting thereby leading to safety concerns (Kuwata, 2006; Takada, 2013; Mrgudich, 1960). One approach to circumvent the safety issue is to replace the liquid electrolytes by solid electrolytes to fabricate all-solidstate batteries (ASSBs), which can deliver an ideal combination of energy density along with operational safety. Hence, ASSBs have attracted significant attention over the years from both fundamental science and technological application point-of-view. The schematic diagrams of battery with liquid electrolyte, solid-state electrolyte and thin film solid-state electrolyte are shown in the Fig. 1A-C.

An all-solid-state battery consists of cathode and anode along with solid electrolyte instead of liquid electrolyte. The working principle of solid-state battery is the same as the conventional liquid

\footnotetext{
*AuthorforCorrespondence: E-mail: rambabua@iisc.ac.in,prabeer@iisc.ac.in
} 


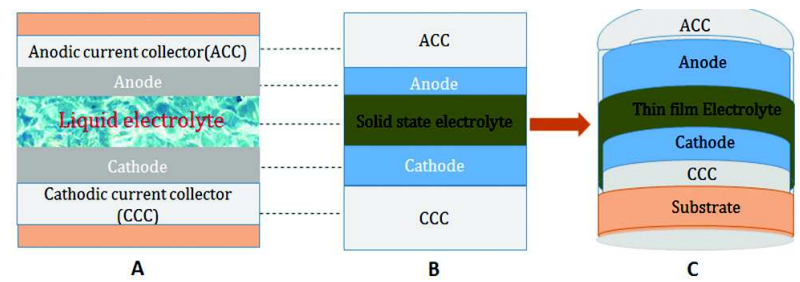

Fig. 1: Schematic diagram of battery with (A) liquid electrolyte (B) solid-state electrolyte and (C) thin film electrolyte

electrolyte based batteries (Bruce, 1997; Yoon, 2013). These batteries can overcome the potential problems of liquid electrolyte based batteries, such aschemical decomposition, safety hazards and flammability. In the quest to realize next generation batteries, all-solidstate batteries form a niche sector encompassing robust energy density and excellent safety (Kotobuki, 2013). In addition, various complicated design/ architecture can be realized in these solid-state batteries. Moving over from organic liquid electrolytes, safe and environmentally compatible solidstate electrolytes have received intense research focus (Li, 1994; Ueda, 2013; Liu, 2014; Bates, 2000; Nishio, 2009). Solid-state electrolytes are mainly classified into two types based on their configurations and electrode/electrolyte materials setups: bulk solid-state electrolytes and thin film solid-state electrolytes. There are two main differences between the bulk and thin film electrolytes: (i) thickness and (ii) fabrication method. While the thickness of bulk solid-state electrolytes is usually in the range of several hundred micrometers; the thin film solid-state electrolytes have thickness in the range of hundreds of nanometers to several micrometers. Bulk solid-state electrolytes are usually manufactured by conventional techniques such as mechanical milling, compaction and high temperature sintering. In contrast, thin film solid-state electrolytes are fabricated by a variety of sophisticated methods like pulsed laser deposition (PLD), spark plasma sintering (SPS), radio frequency sputtering (RF sputtering) and chemical vapor deposition (CVD). The solid-state batteries have slowly but steadily emerged over last three decades. In this review, we have attempted to provide a sneak peek on brief historical journey, various fabrication methods,some state-of-the-art electrode/electrolytes and current status of all-solid-state thin film microbatteries.

\section{A Brief History of All-Solid-State Thin Film Batteries}

All-solid-state thin film batteries were first reported by Hitachi Co. Ltd. (Japan) in 1982. The full cell battery assembly of $\mathrm{TiS}_{2}$ (cathode) $/ \mathrm{Li}_{12} \mathrm{Si}_{3} \mathrm{P}_{2} \mathrm{O}_{20}$ (electrolyte)/Li (anode) was prepared by vapor deposition techniques (Miyauchi, 1983; Kanehori, 1986). However, it was far from commercialization as it was not sufficient for practical applications. NTT Co. Ltd. (Japan) developed a $\mathrm{Li}_{3.4} \mathrm{~V}_{0.6} \mathrm{Si}_{0.4} \mathrm{O}_{4}$ glassy electrolyte based solid-state battery by RF sputtering technique (Ohtsuka, 1989; Ohtsuka, 1990). EvereadyBattery Co. Ltd. (USA) later developed solid-state batteries using sulfide glasses $\left(\mathrm{Li}_{4} \mathrm{P}_{2} \mathrm{~S}_{7}\right.$ and $\mathrm{Li}_{3} \mathrm{PO}_{4}-\mathrm{P}_{2} \mathrm{~S}_{5}$ ) as electrolytes (James, 1988). They improved the battery performance in 1990 s to reach over 1000 cycle performance between $1.5-2.8 \mathrm{~V}$ with capacity of $10-135 \mu \mathrm{Ah} . \mathrm{cm}^{-2}$. At the same time, Bellcore Co. Ltd. (USA) also developed a thin film battery using $\mathrm{LiMnO}_{2}$ cathode, lithium metal anode and lithium borophosphate (LiBP) or lithium phosphorous oxynitride (LiPON) as solid electrolyte (Shokoohi, 1991). The cell showed over 150 cycles operated in the voltage window of 3.5-4.3V giving the capacity around $70 \mu \mathrm{Ah} . \mathrm{cm}^{-2}$. Bates and Dudney et al. at Oak Ridge National Laboratory (ORNL) reported significant progress on LiPON-based thin film batteries, which were produced by RF sputtering technique (Bates, 1993; Bates, 2000; Dudney, 1999). In order to fabricate LiPON thin film batteries, the metallic anode was produced by vacuum evaporation and anodes/cathodes were fabricated by RF sputtering method. LiPON thin films are very stable in air compared to lithium oxide or sulfide based batteries, albeit having low ionic conductivity of $\sim 10^{-6} \mathrm{~S} . \mathrm{cm}^{-1}$. LiPON thin films reported by ORNL showed very good performance between 2-5V with stability over 10,000 cycles. Baba et al. and Park et al., developed the rocking chair type solid-state batteries using $\mathrm{LiMn}_{2} \mathrm{O}_{4}$ cathode $\mid \mathrm{LiPON}$ electrolyte $\mid \mathrm{Li}_{\mathrm{x}} \mathrm{V}_{2} \mathrm{O}_{5}$ anode configuration by RF sputtering technique. They developed solid-state batteries without using Li metallic anode and were successful in obtaining capacity of $\sim 10 \mu \mathrm{Ah} . \mathrm{cm}^{-2}$ (Baba et al., 1999; Baba et al., 2001; Park et al., 1999; Baba et al., 2003). Inspired by these early successes, there have been numerous reports on potential electrodes, solid-state electrolyte materials and design/architecture of superior thin film Li-ion micro-batteries. 
It is known that the battery performance strongly depends on quality of electrode materials and its interfaces (Machida, 2004). While selecting the electrode materials, some key parameters should be taken into account, such as their capacity for energy storage, uniform electrode-electrolyte contact surface area and ability to facilitate reversible lithiation/ delithiation. Although, many different electrode materials have been developed for conventional lithium-ion battery using organic liquid electrolytes, many of these cathodes and anodes developed so far are not yet suitable for solid-state thin film lithium-ion batteries. We have attempted to review promising electrodes (cathodes and anodes) and solid electrolyte materials, suitable for realization of solid-state thin film Li-ion micro-batteries. Some key all-solid-state thin film batteries, reported overthe last 25 years, are enlisted in Table 1. Some salient features of different cathodes, anodes and electrolyte materials are tabulated in Table 2.

\section{Thin film Deposition Techniques}

One key hurdle in realizing efficient thin film microbatteries is to deposit uniform layers of thin films with adequate interfacial contacts with neighboring electrode/electrolytes. There are few vapor deposition techniques that can be employed in order to produce good quality thin film materials. These include simple heating of a source material, laser-induced vaporization, and bombarding the material with energetic ions. All of these techniques are performed under vacuum and primarily rely on the kinetic theory of gases in order to understand their behavior. Some major thin film deposition methods are briefly described below. The schematic diagram of thin film growth mechanism from physical vapor deposition (PVD) techniques is illustrated in Fig. 2. The schematic
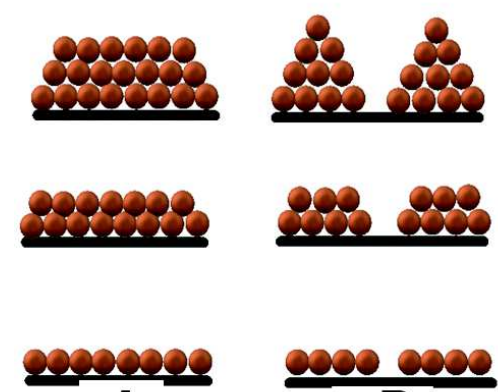

A
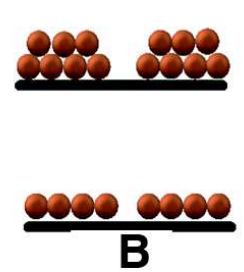

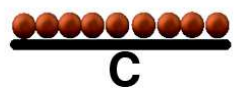

Fig. 2: Schematic diagram of thin film growth models (A) layer by layer (B) Island (C) Layer by layer + Island diagrams of the pulsed laser deposition, RF sputtering and chemical vapor deposition technique are shown in Fig. 3(A-C).

\section{Pulsed Laser Deposition (PLD)}

Pulsed laser deposition (PLD) is a growth technique in which the photon energy of a laser characterized by pulse duration and laser frequency interacts with a bulk material (Chrisey, 1994; Willmott, 2000; Yang, 2000). As a result, material is removed from the surface of target depending on the absorption properties of target materials. Pulsed laser deposition (PLD) involves using a laser beam to vaporize the surface of a target material. In general; the PLD process can be divided into four stages. First, the laser beam is focused onto the target material. The elements in the target are rapidly heated to their evaporation temperature, where there are sufficiently high flux densities over a short pulse duration. Second, the ablated target elements move towards the substrate according to the laws of gas-dynamics. In the third stage, the high energy atoms bombard the substrate surface where a collision region is formed between the incident flow and the sputtered atoms. A film begins to grow after a thermalized region develops and when the condensation rate is higher than the rate of sputtered atoms. Finally, nucleation and growth of a thin-film occurs on the substrate. This step can be controlled by several factors such as laser density, energy, deposition duration, vacuum level and the temperature of the substrate. PLD has some advantages over the other techniques in that, the stoichiometry of the target can be retained in the deposition film, irrespective of composition complexity. Further, many different materials can be deposited with easy handling when compared to other techniques such as CVD and ion implantation techniques (Kaczmarek, 1996; Bao, 2005). On the other hand, it has some disadvantages; such as the deposition of droplets, the splashing or the particulates deposition on the thin-film and lower energy density and slower deposition rate compared to other thin film deposition techniques (Willmott, 2000; Yoshitake, 2001).

\section{Radio Frequency Magnetron Sputtering (RFMS)}

A high-voltage radio frequency (RF) source at a typical frequency of $13.56 \mathrm{MHz}$ is used to ionize a sputtering gas, which produces the plasma (Yamashita, 1999). The ionized gas then bombards the target, 
Table 1: All-solid-state lithium-based thin film batteries reported in the past 25 years

\begin{tabular}{|c|c|c|c|c|c|c|}
\hline Cathode & Anode & Electrolyte & Capacity & Voltage & Year & Ref. \\
\hline $\mathrm{LiMn}_{2} \mathrm{O}_{4}$ & $\mathrm{Li}$ & $\mathrm{Li}_{6.1} \mathrm{~V}_{0.66} \mathrm{Si}_{0.39} \mathrm{O}_{5.36}$ & $33.3 \mathrm{iAh} / \mathrm{cm}^{2}$ & $3.5-5.0$ & 1990 & (Ohtsuka, 1990) \\
\hline $\mathrm{TiS}_{2}$ & $\mathrm{Li} / \mathrm{LiI}$ & $\mathrm{LiI}-\mathrm{Li}_{2} \mathrm{~S}-\mathrm{P}_{2} \mathrm{~S}_{5}-\mathrm{P}_{2} \mathrm{O}_{5}$ & $70 \mathrm{mAh} / \mathrm{cm}^{3}$ & $1.8-2.8$ & 1992 & (Jones, 1992) \\
\hline $\mathrm{LiMn}_{2} \mathrm{O}_{4}$ & $\mathrm{Li}$ & LiPON & $10-30 \mathrm{iAh} / \mathrm{cm}^{2}$ & $4.0-5.3$ & 1995 & (Bates, 1995) \\
\hline $\mathrm{Li}-\mathrm{V}_{2} \mathrm{O}_{5}$ & $\mathrm{Li}$ & LiPON & $10-20 \mathrm{iAh} / \mathrm{cm}^{2}$ & $1.5-3.0$ & 1996 & (Wang, 1996) \\
\hline $\mathrm{LiCoO}_{2}$ & $\mathrm{Li}$ & LiPON & $35 \mathrm{iAh} / \mathrm{cm}^{2}$ & $2.0-4.2$ & 1997 & (Wang, 1996) \\
\hline $\mathrm{Li}_{\mathrm{x}}\left(\mathrm{Mn}_{\mathrm{y}} \mathrm{Ni}_{1-\mathrm{y}}\right)_{2-\mathrm{x}} \mathrm{O}_{2}$ & $\mathrm{Li}$ & LiPON & $100 \mathrm{mAh} / \mathrm{g}$ & $3.5-4.0$ & 1998 & (Neudecker, 1998) \\
\hline $\mathrm{LiMn}_{2} \mathrm{O}_{4}$ & $\mathrm{Li}$ & LiPON & $45 \mathrm{ìh} / \mathrm{cm}^{2}$-ìm & $3.7-4.3$ & 1999 & (Park, 1999) \\
\hline $\mathrm{LiCoO}_{2}$ & $\mathrm{Li}$ & LiPON & $130 \mathrm{iAh} / \mathrm{cm}^{2}$ & $3.5-4.5$ & 2000 & (Bates, 2000) \\
\hline $\mathrm{LiMn}_{2} \mathrm{O}_{4}$ & $\mathrm{~V}_{2} \mathrm{O}_{5}$ & LiPON & $18 \mathrm{iAh} / \mathrm{cm}^{2}$ & $1.0-3.5$ & 2001 & (Baba, 2001) \\
\hline $\mathrm{LiCoO}_{2}$ & $\mathrm{Li}$ & LiPON & $170 \mathrm{mAh} / \mathrm{g}$ & $3.0-4.4$ & 2002 & (Jang, 2002) \\
\hline $\mathrm{LiNiO}_{2}$ & $\mathrm{Li}$ & $\mathrm{Li}_{2.94} \mathrm{PO}_{2.37} \mathrm{~N}_{0.75}$ & $37 \mathrm{ìh} / \mathrm{cm}^{2}$-ìm & $2.0-4.2$ & 2002 & (Kim, 2002) \\
\hline $\mathrm{Li}_{\mathrm{y}} \mathrm{Mn}_{\mathrm{x}} \mathrm{Ni}_{2-\mathrm{x}} \mathrm{O}_{4}$ & $\mathrm{Li}$ & LiPON & $52 \mathrm{ìh} / \mathrm{cm}^{2}$-ìm & $3.0-5.5$ & 2003 & (Whitacre, 2003) \\
\hline $\mathrm{FeS}_{1+\mathrm{x}}$ & $\mathrm{Li}$ & $\mathrm{CPE}$ & $40 \mathrm{mAh} / \mathrm{g}$ & $1.0-2.5$ & 2004 & (Yufit, 2004) \\
\hline $\mathrm{LiMn}_{2} \mathrm{O}_{4}$ & $\mathrm{~V}_{2} \mathrm{O}_{5}$ & LiPON & $13.7 \mathrm{iAh} / \mathrm{cm}^{2}$ & $0.3-3.5$ & 2005 & (Nakazawa, 2005) \\
\hline $\mathrm{LiMn}_{2} \mathrm{O}_{4}$ & $\mathrm{SnO}$ & LVSO & $9 \mathrm{iAh} / \mathrm{cm}^{2}$ & $1.0-2.5$ & 2006 & (Kuwata, 2006) \\
\hline $\mathrm{TiO}_{2}$ & $\mathrm{Li}$ & LiPON & $19 \mathrm{ìh} / \mathrm{cm}^{2}$-ìm & $1.0-3.5$ & 2007 & (Wen, 2007) \\
\hline $\mathrm{CuWO}_{4}$ & $\mathrm{Li}$ & LiPON & 145ìAh/cm²-ìm & $1.0-4.0$ & 2008 & (Ma, 2008) \\
\hline $\mathrm{LiCo}_{1 / 3} \mathrm{Mn}_{1 / 3} \mathrm{Ni}_{1 / 3} \mathrm{O}_{2}$ & $\mathrm{Li}$ & LATSP & $150 \mathrm{mAh} / \mathrm{g}$ & $2.5-4.5$ & 2010 & (Xiea, 2010) \\
\hline $\mathrm{LiCoO}_{2}$ & In & $\mathrm{Li}_{2} \mathrm{~S}-\mathrm{P}_{2} \mathrm{~S}_{5}$ & $46 \mathrm{mAh} / \mathrm{g}$ & $0.0-3.5$ & 2011 & (Sakurai, 2011) \\
\hline $\mathrm{LiCoO}_{2}$ & $\mathrm{Li}$ & LiBPON & $9 \mathrm{iAh} / \mathrm{cm}^{2}$ & $3.4-4.2$ & 2013 & (Yoon, 2013) \\
\hline $\mathrm{LiCoO}_{2}$ & $\mathrm{Sn}_{\mathrm{x}} \mathrm{N}_{\mathrm{y}}$ & LiPON & $163 \mathrm{iAh}$ & $2.0-4.0$ & 2014 & $(\mathrm{Li}, 2014)$ \\
\hline $\mathrm{LiCoO}_{2}$ & $\mathrm{Li}$ & $\mathrm{Li}_{3} \mathrm{PO}_{4-\mathrm{x}} \mathrm{N}_{\mathrm{x}}$ & $103 \mathrm{mAh} / \mathrm{g}$ & $3.5-4.5$ & 2015 & (Nakazawa, 2015) \\
\hline $\mathrm{LiCoO}_{2}$ & $\mathrm{Al}$ & LiPON & $48 \mathrm{iAh} / \mathrm{cm}^{2}$ & $3.0-4.2$ & 2015 & (Gong, 2015) \\
\hline $\mathrm{LiCoO}_{2}$ & $\mathrm{Si}$ & LiPON & $2100 \mathrm{mAh} / \mathrm{g}$ & $2.0-4.0$ & 2016 & (Wang, 2016) \\
\hline $\mathrm{MoO}_{3}$ & $\mathrm{Li}$ & LiPON & $180 \mathrm{iAh} / \mathrm{cm}^{2}$-ìm & $1.0-3.5$ & 2016 & (Glenneberg,2016) \\
\hline $\mathrm{Li}_{4} \mathrm{Ti}_{5} \mathrm{O}_{12}$ & $\mathrm{Li}$ & LiPON & $34 \mathrm{iAh} / \mathrm{cm}^{2}$ & $1.0-2.0$ & 2017 & (Schichtel, 2017) \\
\hline
\end{tabular}
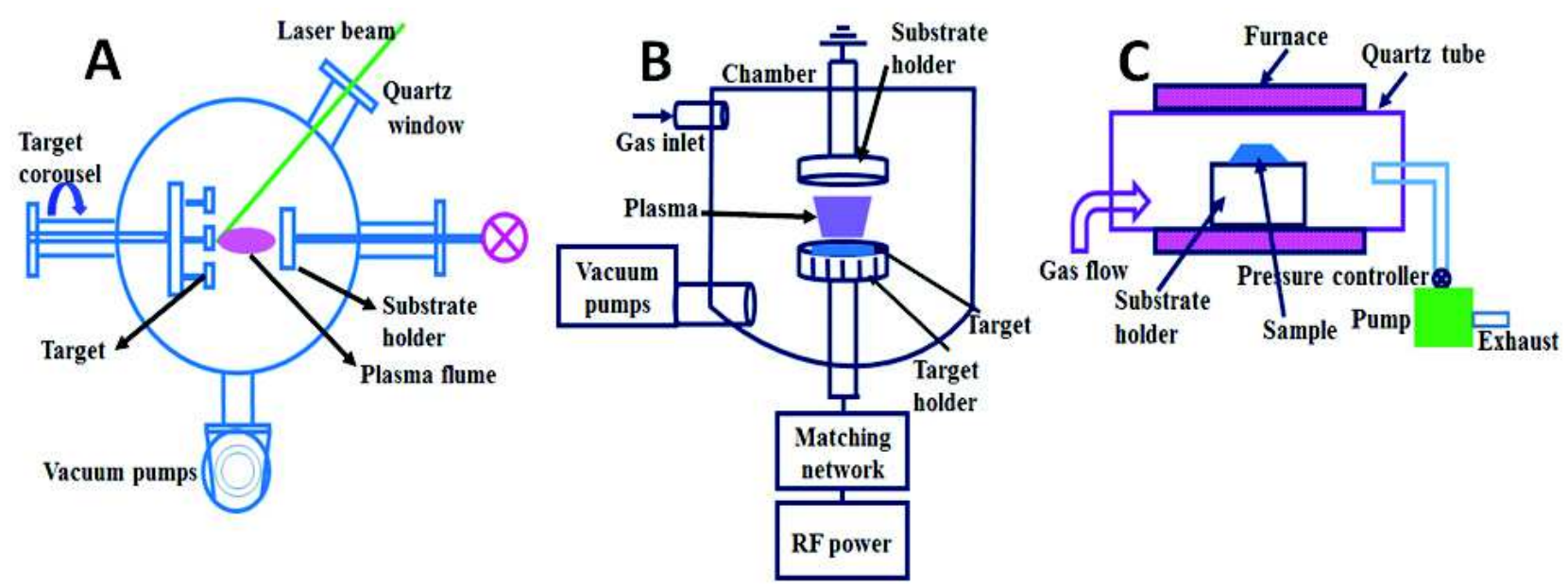

Fig. 3: Schematic diagram of (A) Pulsed laser deposition (B) RF sputtering (C) Chemical vapor deposition 
Table 2: Salient features of difference anode, cathode and electrolyte materials

\begin{tabular}{|c|c|c|c|}
\hline Material & Advantages & Disadvantages & References \\
\hline \multicolumn{4}{|c|}{ Anode materials } \\
\hline $\mathrm{Li}$ & $\begin{array}{l}\text { - High theoretical capacity } \sim 3860 \mathrm{mAh} . \mathrm{g}^{-1} \\
\text { - Low electrochemical potential }(-3.04 \mathrm{~V})\end{array}$ & $\begin{array}{l}\text { - Uncontrollable dendritic Li growth } \\
\text { - Low Coulombic efficiency }\end{array}$ & $\begin{array}{l}\text { (Ohtsuka, 1990) } \\
\text { (Ohtsuka, 1989) }\end{array}$ \\
\hline $\mathrm{V}_{2} \mathrm{O}_{5}$ & $\begin{array}{l}\text { - Theoretical capacity of } \mathrm{V}_{2} \mathrm{O}_{5} \text { is as high } \\
\text { as } \sim 290 \mathrm{~mA} \cdot \mathrm{h}^{-1} \\
\text { - Feasibility of reversible insertion and } \\
\text { extraction of lithium ions } \\
\text { - Low cost }\end{array}$ & $\begin{array}{l}\text { - Poor stability } \\
\text { - Low ionic and electronic conductivity }\end{array}$ & $\begin{array}{l}\text { (Nakazawa, 2005) } \\
\text { (Nakazawa, 2007) } \\
\text { (Baba, 2003) }\end{array}$ \\
\hline $\mathrm{Al}$ & - Theoretical capacity of $\sim 2235 \mathrm{mAh} \cdot \mathrm{g}^{-1}$ & $\begin{array}{l}\text { - Short cycle life\& large volume } \\
\text { - High irreversible capacity loss }\end{array}$ & (Gong, 2015) \\
\hline $\mathrm{Si}$ & - Highest theoretical capacity $\sim 4200 \mathrm{mAh} . \mathrm{g}^{-1}$ & $\begin{array}{l}\text { - Large volumetric changes } \\
\text { - Large electrochemically related stress } \\
\text { - Early capacity fading }\end{array}$ & $\begin{array}{l}\text { (Tong, 2014) } \\
\text { (Polat, 2015) } \\
\text { (Polat, 2016) }\end{array}$ \\
\hline \multicolumn{4}{|c|}{ Cathode materials } \\
\hline $\mathrm{LiCoO}_{2}$ & $\begin{array}{l}\text { - High theoretical capacity } \sim 274 \mathrm{mAh} \cdot \mathrm{g}^{-1} \\
\text { - Theoretical capacity } \sim 170 \mathrm{mAh} \cdot \mathrm{g}^{-1} \\
\text { - Long cycle life } \\
\text { - Easy operation at high temperature } \\
\text { - Low self-discharge }\end{array}$ & $\begin{array}{l}\text { - Expensive } \\
\text { - Low thermal stability }\end{array}$ & $\begin{array}{l}\text { (Wang, 1995) } \\
\text { (Whitacre, 2001) } \\
\text { (Hayashi, 2007) } \\
\text { (Kuwata, 2010) } \\
\text { (Jacke, 2010) }\end{array}$ \\
\hline $\mathrm{LiNiO}_{2}$ & $\begin{array}{l}\text { - High theoretical capacity } \sim 275 \mathrm{mAh} . \mathrm{g}^{-1} \\
\text { - High energy density }\end{array}$ & $\begin{array}{l}\text { - Thermally unstable } \\
\text { - Blocking of } \mathrm{Li}^{+} \text {ion pathways during } \\
\text { process }\end{array}$ & (Kim, 2002) \\
\hline $\begin{array}{l}\mathrm{LiNi}_{\mathrm{x}} \mathrm{Co}_{\mathrm{y}} \\
\mathrm{Mn}_{\mathrm{z}} \mathrm{O}_{2}\end{array}$ & $\begin{array}{l}\text { - High theoretical capacity } \sim 280 \mathrm{mAh} \cdot \mathrm{g}^{-1} \\
\text { - Good cycle stability and low cost }\end{array}$ & & $\begin{array}{l}\text { (Kim, 2002) } \\
\text { (Wang, 2017) } \\
\text { (Kun, 2017) }\end{array}$ \\
\hline $\mathrm{LiFePO}_{4}$ & $\begin{array}{l}\text { - Theoretical capacity } \sim 170 \mathrm{mAh} \cdot \mathrm{g}^{-1} \\
\text { - Thermal stability } \\
\text { - High power capabilities }\end{array}$ & $\begin{array}{l}\text { - Low operating voltage } \sim 3.2 \mathrm{~V} \text {. } \\
\text { Low ionic and electronic conductivity }\end{array}$ & $\begin{array}{l}\text { (Xie, 2009) } \\
\text { (Bajars, 2011) } \\
\text { (Alexis, 2016) }\end{array}$ \\
\hline $\mathrm{LiMnPO}_{4}$ & $\begin{array}{l}\text { - Theoretical capacity } \sim 170 \mathrm{mAh} \cdot \mathrm{g}^{-1} \\
\text { - Operational voltage } \sim 4 \mathrm{~V} \\
\text { - High specific energy }\end{array}$ & - Low ionic and electronic conductivity & $\begin{array}{l}\text { (Baba, 2001) } \\
(\text { Park, 1999) }\end{array}$ \\
\hline $\mathrm{LiCoPO}_{4}$ & $\begin{array}{l}\text { - Theoretical capacity } \sim 165 \\
\text { - High operational voltage } \sim 4.2 \mathrm{~V}\end{array}$ & $\begin{array}{l}\text { - Expensive } \\
\text { - Low ionic and electronic conductivity }\end{array}$ & $\begin{array}{l}(\mathrm{Li}, 2006) \\
(\mathrm{Li}, 2008)\end{array}$ \\
\hline \multicolumn{4}{|c|}{ Electrolyte materials } \\
\hline LiPON & $\begin{array}{l}\text { - High ionic conductivity } \sim 3.3 \times 10^{-6} \mathrm{~S} / \mathrm{cm} \\
\text { - Excellent electrochemical stability. } \\
\text { - High operational potential } \sim 5.5 \mathrm{~V}\end{array}$ & & $\begin{array}{l}\text { (Bates, 1992) } \\
(\text { Yu, 1997) } \\
\text { (Vereda, 2002) } \\
\text { (Kim, 2008) }\end{array}$ \\
\hline $\mathrm{Li}_{10} \mathrm{GeP}_{2} \mathrm{~S}_{12}$ & 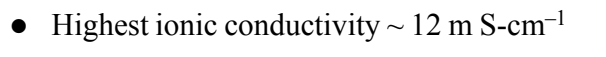 & & Noriaki (2011) \\
\hline $\mathrm{Li}_{2} \mathrm{~S}-\mathrm{P}_{2} \mathrm{~S}_{5}$ & - High ionic conductivity $\sim 2 \times 10^{-6} \mathrm{~S} / \mathrm{cm}$ & $\begin{array}{l}\text { - Electrolyte instability } \\
\text { - Large increase in cell resistance }\end{array}$ & $\begin{array}{l}\text { (Kbala, 1984) } \\
\text { (Yamashita, 1996) }\end{array}$ \\
\hline LVSO & $\begin{array}{l}\text { - Ionic conductivity } \sim 2.5 \times 10^{-7} \mathrm{~S} / \mathrm{cm} \\
\text { - Low voltage window around } 3.5 \mathrm{~V}\end{array}$ & Electronic conductivity $\sim 10^{-10} \mathrm{~S} / \mathrm{cm}$ & $\begin{array}{l}\text { (Yamashita, 2001) } \\
\text { (Kawamura, 2004) }\end{array}$ \\
\hline LLTO & - Highest ionic conductivity of $10^{-3} \mathrm{~S} / \mathrm{cm}$ & $\begin{array}{l}\text { - Highly unstable } \\
\text { - Choice of electrodes are limited. } \\
\text { Cathodic potential }>2.4 \mathrm{~V} \text { will react with } \\
\text { electrolyte }\end{array}$ & $\begin{array}{l}\text { (Kitaoka, 1997) } \\
\text { (Stramare, 2003) } \\
\text { (Lee, 2006) } \\
\text { (Maqueda, 2008) }\end{array}$ \\
\hline
\end{tabular}


where multiple collisions take place, releasing atoms of the target material into the plasma. These atoms condense upon the substrate, which is placed in front of the target. A permanent magnet is added to the sputtering gun in order to enhance the deposition rate and minimize the secondary electron bombardment of the film. There are several important reasons for selecting radio-frequency magnetron sputtering (RFMS) as the technique of choice. First, there is no need to produce thick films. To produce a protective barrier for lithium metal anodes, a layer is needed and it only needs to be thick enough so that it does not have large numbers of pin holes that will lead to failure of the anode. A layer of 50 to $5000 \AA$ is considered to be thick enough and can easily be produced by RFMS. In addition, sputtering can be done within the confines of a sealed glovebox. It can be used with multiple targets and film chemistries to produce very uniform films of high compositional integrity and it consequently produces films with excellent adherence to the substrate. Finally, it is possible to deposit insulator films through RF reactive sputtering at rates higher than those of direct current methods (Dudney, 1999; Souquet, 2002).

\section{Chemical Vapor Deposition (CVD)}

Chemical Vapor Deposition (CVD) process is related to transforming gaseous molecules and precursors by chemical reaction occurring on the heated substrate surface. CVD can be capable of making material, is in the form of a thin-film, powder or single crystal (Mount, 2003). By optimizing the experimental conditions, including composition of reaction gas mixture, substrate temperature, and substrate material etc., materials with wide range of physical and chemical properties can be grown. The characteristic feature of the CVD is its excellent throwing power, deposition of uniform thickness over large surfaces and selective deposition on patterned substrates. CVD processing is widely used in various fields such as integrated circuits, optoelectronic devices, sensors, micro-machines and fine metal and ceramic powders. CVD has many advantages compared to physical vapor deposition (PVD) techniques such as sputtering and molecular beam evaporation. While PVD processes may not give complete conformal coverage due to a shadowing effect, CVD can be allowed to coat thin-films of three dimensional structures with large aspect ratios. The deposition rates of the CVD process are several times higher than those of PVD routes. In addition, ultra-high vacuum is not needed and high purity films can be produced by CVD process. However, there are some disadvantages of the CVD process. It employs high deposition temperature(over $600^{\circ} \mathrm{C}$ ), which is not suitable for already grown thin films on substrates. CVD precursors are at time dangerous and toxic, which calls for strict safety measures. Further, metal organic chemical vapor deposition (MOCVD) needs very expensive precursors.

\section{Thin Film Cathodes: Metal Oxides and Chalcogenides}

Cathode materials play an important role in supporting the lithium ion(de) intercalation process in secondary Li-ion thin film batteries. A good cathode material is expected to have light weight, superior energy/power density, limited self-discharge and robust cycling stability (Whittingham, 2004). The first ever thin-film cathode ( $\mathrm{TiS}_{2}$ chalcogenide) was deposited by CVD and was incorporated into thin film lithium battery by Hitachi Central Research Laboratory (Kanehori, 1983; Kanehori, 1986). These films were composed of small plate-like crystals randomly intersecting each other. They exhibited very promising electrochemical activity involving efficient $\mathrm{Li}^{+}$diffusion delivering about $55 \%$ of its theoretical capacity at a current density of $16 \mathrm{~mA} \cdot \mathrm{cm}^{-2}$. Later, Meunier et al., fabricated $\mathrm{TiO}_{\mathrm{x}} \mathrm{S}_{\mathrm{y}}$ amorphous thin films via sputtering (Meunier, 1989). These micro-batteries were constructed using amorphous thin-film cathode with the composition $\mathrm{TiO}_{1.5} \mathrm{~S}_{0.7}$ with an open circuit voltage (OCV) of 2.6 $\mathrm{V}$. These cells were expected to support relatively high current densities, upto $62 \mathrm{~mA} \cdot \mathrm{cm}^{-2}$, but the corresponding capacity obtained was $23 \%$ of the first discharge capacity at current density of $1 \mathrm{~mA} . \mathrm{cm}^{-2}$ due to the low diffusion co-efficient of the cathode material. However, Eveready Battery Company could commercialize a thin-film lithium battery with $\mathrm{TiS}_{2}$ cathode deposited by radio-frequency sputtering (Steven, 1995). The deposited film had good stoichiometry $\left(\mathrm{TiS}_{2.09}\right)$ with small crystallites that resulted in very large active surface area favoring easy $\mathrm{Li}^{+}$intercalation into the cathode thin film. Thin film batteries constructed with $\mathrm{TiS}_{2}$ cathode film had an OCV around $2.5 \mathrm{~V}$ and exhibitedover 1000 cycles between 1.4 and $2.8 \mathrm{~V}$, retaining over $90 \%$ cathode utilization at current densities up to $300 \mathrm{~mA} . \mathrm{cm}^{-2}$. 
Following, metal sulfide (nickel sulfide) thin films were developed by Matsumura et al., as cathode for thin film batteries(Matsumura, 2007; Yufit, 2004). The $\mathrm{Ni}_{3} \mathrm{~S}_{2} \mid$ LISICON $\mid$ Al-Li all-solid-state cell delivered a large reversible capacity of $300 \mathrm{mAh} \cdot \mathrm{g}^{-1}$ even after 300 cycles (Matsumura, 2007). The wt. $\%$ of $\mathrm{Ni}_{3} \mathrm{~S}_{2}$ plays an important role to exhibit stable reversible capacities. As the depth of the first discharge capacity also influences the cycling properties, $\mathrm{Ni}_{3} \mathrm{~S}_{2}$ consumed during the discharge reaction may affect the nickel reduction mechanism. Following, iron sulfide thin film incorporated into a $\mathrm{Li}|\mathrm{CPE}| \mathrm{FeS}_{\mathrm{x}}$ cell showed good electrochemical performance over 650 cycles with $0.06 \%$ capacity fade per cycle and near $100 \%$ Coulombic efficiency at a current density of 50 $\mathrm{mA} . \mathrm{cm}^{-2}$ at $125^{\circ} \mathrm{C}$ (Yufit, 2004). Apart from metal sulfides, metal oxides and selenides were also successfully incorporated into thin-film lithium batteries. However, the fabricated selenide thin-films with the structure of $\mathrm{Li} \mid \mathrm{Li}^{+}$-borate glass $\mid \mathrm{InSe}$ delivered very poorcapacity. NTT Co. Ltd. (Japan) fabricated several thin-film lithium batteries with different metal oxides such as $\mathrm{WO}_{3-\mathrm{x}}, \mathrm{MnO}_{2-\mathrm{x}}$ and $\mathrm{MoO}_{3-\mathrm{x}}$ cathodes using RF sputtering method (Yamaki, 1996; Ohtsuka, 2001). Among them, $\mathrm{MoO}_{3-\mathrm{x}}$ thin film with a thickness of $\sim 4.66 \mu \mathrm{m}$ showed an initial discharge capacity of $398 \mathrm{mAh} . \mathrm{cm}^{-2}$ per unit area up to 40 cycles. The charge-discharge curves and discharge curves at different cycles of $\mathrm{Li} / \mathrm{MoO}_{3-\mathrm{x}}$ thin films are shown in Fig. 4(A-B). The polarization between charge and discharge curves at 20th cycle was only about $0.3 \mathrm{~V}$. It was observed that increasing the cathode film thickness slightly reduced the cathode utilization at a high discharge current density, but the discharge capacity increased. Some other oxide based thin films such as $\mathrm{V}_{2} \mathrm{O}_{5}$ (Bates, 1993; Eun, 2001; Danmei, 2014), $\mathrm{TiO}_{2}$ (Wen-Yen, 2007), $\mathrm{Fe}_{2} \mathrm{O}_{3}$ (Kitaura, 2007), $\mathrm{V}_{2} \mathrm{O}_{5}-\mathrm{WO}_{3}$ (Kirino, 1986), $\mathrm{V}_{2} \mathrm{O}_{5}$ $\mathrm{TeO}_{2}$ (Jourdaine, 1988), $\mathrm{V}_{2} \mathrm{O}_{5}-\mathrm{P}_{2} \mathrm{O}_{5}$ (Jourdaine, 1988), $\mathrm{NiCo}_{2} \mathrm{O}_{4}-\mathrm{NiFe}_{2} \mathrm{O}_{4}$ and $\mathrm{MoO}_{3}$ (West, 2005; Zheng, 2015; Choi, 2017) were also successfully integrated into thin film lithium batteries by several groups. While metal chalcogenides are electrochemically active, they have several practical issues including low operational voltage. Thus, battery scientists moved over to explore Li-based transition metal oxides as efficient thin-film battery components.

\section{Lithium Transition Metal Oxides}

Layer structured lithium transition metal oxides are the most popular cathode materials for commercial lithium-ion thin film batteries. Researchers at Oak Ridge National Laboratory first introduced $\mathrm{LiCoO}_{2}$ as cathode for thin film batteries, which is a wellknown member in the layer oxide family (Wang, 1996). These $\mathrm{LiCoO}_{2}$ thin films were deposited by planar RF sputtering and were subjected to various postannealing temperatures. By optimizing several processing conditions, films annealed at $700^{\circ} \mathrm{C}$ was found to exhibit superior capacity retention with minimal lossofaround $0.0001-0.002 \%$ /cycle for over 100 cycles for microbatteries with cathode film thickness 0.05-0.5 $\mu \mathrm{m}$. Later, the same group successfully fabricated thin film Li-ion batteries based
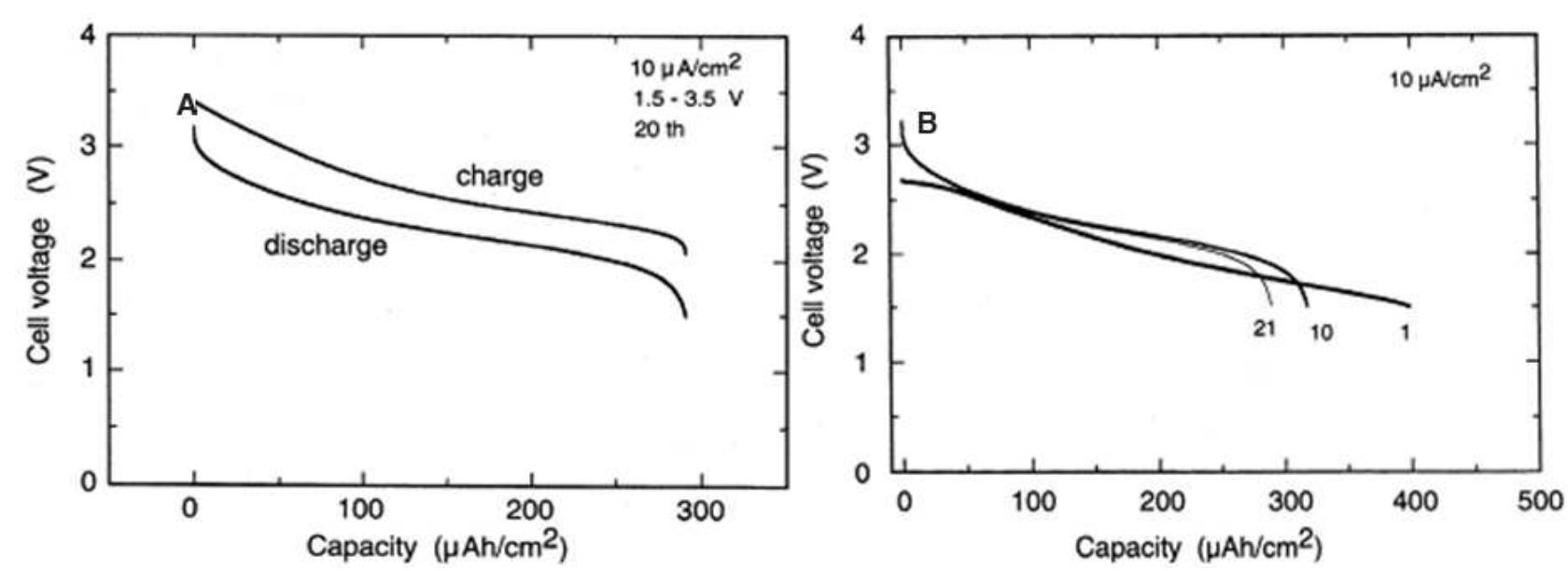

Fig. 4: (A) Charge-discharge curvesof $\mathrm{Li} / \mathrm{MoO}_{3-\mathrm{x}}$ thin film battery (B) discharge curves at different cycles. Reproduced from reference (Ohtsuka, 2001) 
on $\mathrm{LiCoO}_{2}$ cathodes (Neudecker, 1999). These exciting results attracted the attention of several research groups towards $\mathrm{LiCoO}_{2}$-based thin film lithium/lithium-ion batteries (Whitacre, 2001; Hayashi, 2007; Kuwata, 2010; Kuwata, 2004; Jacke, 2010). The Jet Propulsion Laboratory (JPL at California Institute of Technology) deposited $\mathrm{LiCoO}_{2}$ thin films at low temperature (ca. $300^{\circ} \mathrm{C}$ ) using RF sputtering delivering good electrochemical properties suitable for micro-batteries. Later, NTT Corporation (Japan) employed electron cyclotron resonance (ECR) sputtering method to prepare $\mathrm{LiCoO}_{2}$ thin films (Hayashi, 2007). These films were well crystallized without any post heating by controlling the $\mathrm{O}_{2}$ to $\mathrm{Ar}$ ratio. A full cell battery using $\mathrm{LiCoO}_{2}$ thin film (thickness: $6.2 \mu \mathrm{m}$ ) delivered relatively large discharge capacity around $250 \mathrm{mAh} . \mathrm{cm}^{-2}$ with steady cyclability. Moreover, this battery exhibited high discharge capacities over $100 \mathrm{mAh} . \mathrm{cm}^{-2}$ along with excellent rate performance. The feasibility of preparing thin film batteries on flexible polymer substrate was demonstrated successfully. Kuwata et al., used PLD route to fabricate $\mathrm{LiCoO}_{2}$ thin films (Kuwata, 2010; Kuwata, 2004) to construct lithium/lithium-ionthin film batteries. In-situ photoelectron spectroscopy was utilized to investigate $\mathrm{LiCoO}_{2} \mid \mathrm{LiPON}$ interface at different temperatures during the deposition of LiPON solid electrolyte (Jacke, 2010). It was observed that an intermediate layer composed of some new nitrogen-containing species affects the interface dipole modifying the electronic structure at the heterogeneous $\mathrm{LiCoO}_{2} \mid \mathrm{LiPON}$ interface. Liu et al. tested the electrical performance of Li $\mid$ LiPON | $\mathrm{LiCoO}_{2}$ all-solid-state thin film lithium battery $(\mathrm{Li}$, 2008). The results showed that $\mathrm{LiCoO}_{2}$ thin film annealed at $700^{\circ} \mathrm{C}$ exhibited best performance with a clear discharge plateau observed between 3.8-4.2 V. The specific capacity reached $55.4 \mathrm{mAh} . \mathrm{cm}^{-2} \cdot \mu \mathrm{m}^{-1}$ with a good cyclic performance. Sivaji et al. studied $\mathrm{Zr} / \mathrm{Ti}$ doped $\mathrm{LiCoO}_{2}$ thin films prepared by RF sputtering, which revealed the enhancement of discharge capacity upon $\mathrm{Zr} / \mathrm{Ti}$ doping vis-a-vis pristine $\mathrm{LiCoO}_{2}$ thin films. Similarly, $\mathrm{Zr}$-doped $\mathrm{LiCoO}_{2}$ films were found to exhibit stable electrochemical performance (Sivaji, 2016).

Besides lithium cobalt oxides, other layer structure lithium transition metal oxide thin films, such as $\mathrm{Li}_{\mathrm{x}}\left(\mathrm{Mn}_{\mathrm{y}} \mathrm{Ni}_{1-\mathrm{y}}\right)_{2-\mathrm{x}} \mathrm{O}_{2}$ (Neudecker, 1998), $\mathrm{LiNiO}_{2}$
(Kim, 2002), $\mathrm{LiNi}_{1-\mathrm{x}} \mathrm{Co}_{\mathrm{x}} \mathrm{O}_{2}$ (Kim, 2002; Wang, 2017; Kun, 2017), $\mathrm{LiCo}_{0.8} \mathrm{M}_{0.2} \mathrm{O}_{2}(\mathrm{M}=\mathrm{Ni}, \mathrm{Zr})(\mathrm{Li}, 2006)$, $\mathrm{LiNi}_{0.8}-\mathrm{Co}_{0.2} \mathrm{O}_{2}$ (Baskaran, 2009) and $\mathrm{Li}\left(\mathrm{Ni}_{1 / 4} \mathrm{Mn}_{1 /}\right.$ $\left.{ }_{2} \mathrm{Co}_{1 / 4}\right) \mathrm{O}_{2}$ (Ding, 2010) were successfully explored for thin film lithium/lithium-ion batteries. Ding et al. fabricated $\mathrm{Li}\left(\mathrm{Ni}_{1 / 4} \mathrm{Mn}_{1 / 2} \mathrm{Co}_{1 / 4}\right) \mathrm{O}_{2}|\mathrm{LiPON}| \mathrm{Li}$ thin film batteries with capacity increasing upon longer cycling due to the gradual improvement of the interface between cathode and electrolyte (Ding, 2010). A reversible capacity of $30 \mathrm{mAh} \cdot \mathrm{cm}^{-2} \cdot \mu \mathrm{m}^{-1}$ was achieved between 3-5 V. Exploring spinel oxide materials, Bellcore and Eveready Battery Co. (USA) fabricated thin film battery with crystalline $\mathrm{LiMn}_{2} \mathrm{O}_{4}$ as cathode and LIPONas electrolyte (Jones, 1994). It showed approximately $75 \% \mathrm{Li}$ intercalation into cathode materials when cycled between 3.5 and 4.3 $\mathrm{V}$ at current densityof $30 \mathrm{~mA} \cdot \mathrm{cm}^{-2}$. Park et al. fabricated a full cell thin film battery using $\mathrm{LiMn}_{2} \mathrm{O}_{4}$ LiPON | Li architecture (Park, 1999). It exhibited reversible discharge capacity of approximately 48 mAh.cm-2 corresponding to $0.8 \mathrm{Li}$ per mole of $\mathrm{Mn}_{2} \mathrm{O}_{4}$ involving a sharp plateau around $4 \mathrm{~V}$. The capacity loss was less than $4 \%$ after 100 cycles at a current density of $100 \mathrm{~mA} \cdot \mathrm{cm}^{-2}$. By interconnecting 8 unit cells in series, they also achieved a high voltage of approximately $32 \mathrm{~V}$.A thin film battery with nanocrystalline $\mathrm{Li}_{\mathrm{x}} \mathrm{Mn}_{2-\mathrm{y}} \mathrm{O}_{4}$ cathode film was fabricated at Oak Ridge National Laboratory (Dudney, 1999). In nanocrystalline films, it was observed that the $\mathrm{Li}^{+}$diffusivity was greatly reduced, thereby limiting its power density. The advantage of this cathode wasthe ability to fabricate thin-film batteries on substrates maintained at low temperature or temperature-sensitive devices. Furthermore, these batteries also proved to be very stable with long cycle life even when operated at high temperature up to $100^{\circ} \mathrm{C}$. Baba et al. incorporated $\mathrm{LiMn}_{2} \mathrm{O}_{4}$ spinel films into a thin-film lithium-ion battery (Baba, 2001). Several other transition metal oxides were developed by Whitacre et al. They successfully demonstrated a new method to fabricate hundreds of cells with slightly different cathode compositions in less than $10 \mathrm{~h}$ and subsequently analyzed them using traditional electrochemical techniques (Whitacre, 2003). Zhou fabricated $\mathrm{ZrO}_{2}$-doped $\mathrm{LiMn}_{2} \mathrm{O}_{4}$ thin film by RF magnetron sputtering ( $\mathrm{Li}, 2007)$. It was found that $\mathrm{ZrO}_{2}$ doping lowered the particle size of as deposited thin films. The electrochemical testing of $\mathrm{LiMn}_{2} \mathrm{O}_{4}{ }^{-}$ $\mathrm{ZrO}_{2} \mid$ LiPON $\mid \mathrm{Li}$ solid-state thin film batteries 
exhibited a gradually sloping discharge plateau between 4.0 to $2.0 \mathrm{~V}$, while the undoped one showed two flat discharge plateaus at $4.0 \mathrm{~V}$ and $2.8 \mathrm{~V}$. It was predicted that adding $\mathrm{ZrO}_{2}$ substantially enfeebled the free energy in annealed $\mathrm{LiMn}_{2} \mathrm{O}_{4}-\mathrm{ZrO}_{2}$ thin film, which led to smaller particle size affecting their electrochemical kinetics. The films with sloping voltage plateau can more suitable for certain practical applications than the films having distinct plateaus.

\section{Polyanionic Compounds}

Moving from oxides to polyanionic cathode systems, lithium transition metal phosphate thin films were studied by several groups (Sauvage, 2004; Iriyama, 2004; $\mathrm{Ma}, 2005)$. $\mathrm{LiCoPO}_{4}$ and $\mathrm{LiMnPO}_{4}$ were the first systems to be implemented in thin-film lithium batteries (West, 2003; Ma, 2005; Fujimoto, 2015). Unfortunately, these thin films exhibited poor discharge capacity of $11 \mathrm{mAh} . \mathrm{cm}^{-2}$ for $\mathrm{LiCoPO}_{4}$ (at a rate of $\mathrm{C} / 15$ ) and 5-20 mAh.g ${ }^{-1}$ for $\mathrm{LiMnPO}_{4}$ (at current density of $20 \mathrm{mV} \cdot \mathrm{min}^{-1}$ ) in comparison to previously discussed layered oxide and spinel oxide cathodes. At this nascent stage, various other polyanionic systems must be investigated to find suitable candidates for thin film lithium/lithium-ion batteries. In this spirit, $\mathrm{LiFePO}_{4}$ thin films have been extensively studied by varying deposition techniques, substrates, and deposition temperature etc. (Sauvage, 2007; Xie, 2009; Alexis, 2016; Bajars, 2011; Pana, 2018). Notably, Pana et al. introduced a new way of hydrothermal process to fabricate homogeneous and continuous carbon coated nitrogenated $\mathrm{LiFePO}_{4} / \mathrm{N}-\mathrm{C}$ films. The $\mathrm{LiFePO}_{4} / \mathrm{N}-\mathrm{C}$ films deposited on carbon clothed substrate exhibited a near theoretical high capacity of $169 \mathrm{mAh}^{-1} \mathrm{~g}^{-1}$ at $1 \mathrm{C}$. It was observed that nanopores and $\mathrm{N}-\mathrm{C}$ coating favored fast $\mathrm{Li}^{+}$diffusion and electronic conductivity, thereby leading to superior electrochemical properties (Pana, 2018). In parallel, Fu group investigated a series of polyanion compounds to fabricate thin film lithium batteries. Initially, nitrogen doped-FePO ${ }_{4}(\mathrm{FePON})$ as implemented as cathode to form FePON | LiPON | Li full cell. Interestingly, the FePON thin film micro-batteries showed a higher capacity and better cycling performance than pristine $\mathrm{FePO}_{4}$ micro-batteriesdue to improved electronic conductivity with nitrogenation ( $\mathrm{Li}, 2006)$. Later, same group worked on other polyanionic materials likeLiFe $\left(\mathrm{WO}_{4}\right)_{2}(\mathrm{Li}, 2008 ; \mathrm{Li}, 2009 ; \mathrm{Li}, 2008)$. An all-solidstate thin film battery $\mathrm{LiFe}\left(\mathrm{WO}_{4}\right)_{2}|\mathrm{LiPON}| \mathrm{Li}$ with a new amorphous cathode of $\mathrm{LiFe}\left(\mathrm{WO}_{4}\right)_{2}$ was constructed. It delivered a reversible capacity of 220 $\mu \mathrm{Ah} . \mathrm{cm}^{-2}$ involving two redox centers $\left(\mathrm{Fe}^{3+} / \mathrm{Fe}^{2+}\right.$ and $\mathrm{W}^{6+} / \mathrm{W}^{\mathrm{x}^{+}}$, where, $\mathrm{x}=4$ or 5 ) with excellent capacity retention over 1000 cycles. It exhibited much better rate capacity in comparison to $\mathrm{LiCoO}_{2}$ and $\mathrm{LiMn}_{2} \mathrm{O}_{4}$ thin films due to its favorable electrode-electrolyte interface. $\mathrm{LiFe}\left(\mathrm{WO}_{4}\right)_{2}$ thin film was proposed to be a suitable electrode material for application in all-solidstate thin film lithium batteries. Polyanionic systems offer virtually infinite number of cathode materials, which should be systematically explored to unravel efficient thin film cathode materials.

\section{Thin Film Anodes}

Anode (or the negative insertion) materials act as host to reversibly accommodate $\mathrm{Li}^{+}$coming from cathodes during battery operation. Broadly speaking, all-solidstate thin film batteries widely use Li metal as anode. However, the low melting point and its strong reactivity with moisture restricted the use of Li metal in reallife thin film batteries. In addition, the choice of electrolytes that are stable enough for use with metallic lithium is also limited. Therefore, it is mandatory to find suitable anode candidates to realizethin film lithium-ion full cell. Nevertheless, when compared with the volume of work on cathode films, the research on anode films is quite sparse with only limited numbers of known compounds tested in thin film lithium-ion batteries. Bates et al. tested several nitrides as anodes such as silicon-tin oxynitrides (SiTON), $\mathrm{Zn}_{3} \mathrm{~N}_{2}$ and $\mathrm{Sn}_{3} \mathrm{~N}_{4}$ (Neudecker, 1999; Bates, 2000). Among them, a $\mathrm{LiCoO}_{2}|\mathrm{LiPON}|$ SiTON cell delivered a reversible discharge capacity around $340 \mathrm{mAh} \cdot \mathrm{g}^{-1}$. This full cell exhibited robust cycling stability between 3.93-2.7 V with capacity fading of only $0.001 \%$ per cycle. Baba et al. fabricated several thin-film lithium-ion batteries based on $\mathrm{V}_{2} \mathrm{O}_{5}, \mathrm{Nb}_{2} \mathrm{O}_{5}$ as anode and $\mathrm{LiMn}_{2} \mathrm{O}_{4}$ spinel as cathode (Dudney,1999; Nakazawa, 2005; Nakazawa, 2007; Baba, 2003). They examined the electrochemical properties by varying the thickness of $\mathrm{Nb}_{2} \mathrm{O}_{5}$. The results revealed that the batteries with a negative electrode thickness of $\sim 200 \mathrm{~nm}$ showed an unstable cycling behavior consisting of a two-step curve, while the batteries with a negative electrode thinner than $100 \mathrm{~nm}$ showed a stable cycling curve up to 500 cycles. Lee et al. developed a $\mathrm{Si}-\mathrm{V}$ anode film with the stoichiometry of $\mathrm{Si}_{0.7} \mathrm{~V}_{0.3}$ and constructed a $\mathrm{LiCoO}_{2}|\mathrm{LiPON}| \mathrm{Si}_{0.7} \mathrm{~V}_{0.3}$ cell (Lee, 2003). It 
exhibited an excellent cycling stability between 2-3.9 $\mathrm{V}$ delivering a reversible discharge capacity of $\sim 50$ $\mathrm{mAh} \cdot \mathrm{cm}^{-1} \cdot \mathrm{mm}^{-1}$ Kuwata et al. obtained $\mathrm{SnO}$ anode thin film by PLD and constructed several thin-film lithium-ion batteries with $\mathrm{LiCoO}_{2}, \mathrm{LiNi}_{0.8} \mathrm{Co}_{0.2} \mathrm{O}_{2}$ and $\mathrm{LiMn}_{2} \mathrm{O}_{4}$ (Kuwata, 2006). To match the $\mathrm{Li}$ free cathode, Baba et al. fabricated $\mathrm{Li}_{\mathrm{x}} \mathrm{V}_{2} \mathrm{O}_{5}$ anode films (Baba, 1999; Lee, 1999) by electrochemical lithiation of as-deposited $\mathrm{V}_{2} \mathrm{O}_{5}$ thin film to a potential of $0.1 \mathrm{~V}$ (vs. Li) before cell operation. Lee et al. fabricated the same compound by thermally evaporating pure $\mathrm{Li}$ metal on to the $\mathrm{V}_{2} \mathrm{O}_{5}$ layer at room temperature to form $\mathrm{Li}_{8} \mathrm{~V}_{2} \mathrm{O}_{5}$ anode (Lee, 1999). Both kinds of cells showed a very stable cycling performance. An insitu SPM study was made on $\mathrm{TiO}_{2}$ anode within an all-solid-state thin film lithium battery $\left(\mathrm{LiNi}_{1 / 3} \mathrm{Co}_{1 /}\right.$ ${ }_{3} \mathrm{Mn}_{1 / 3} \mathrm{O}_{2}|\mathrm{LiPON}| \mathrm{TiO}_{2}$ ) (Zhu, 2012). Revealing cyclic expansion/contraction during Li-ion insertion/ extraction processes. On another note, $\mathrm{Si}$ can in principle, work as a high capacity anode material for Li-ion batteries. However, it does not present pragmatic candidate for anode materials due to its extreme volume changes (over $300 \%$ ) that leads to poor cycling stability and material degradation. Recently, many researchers observed that nanoscale Si materials can decrease the volume stress resulting in promoting superior cyclability than bulk Si (Tong, 2014; Polat, 2015; Polat, 2016). The charge-discharge curves and rate capability of $\mathrm{Si} / \mathrm{C}$ thin films are shown in Fig. 5(A-B). Recently, we fabricated Ti-based $\mathrm{SrLi}_{2} \mathrm{Ti}_{6} \mathrm{O}_{14}$ anode thin-films on SS substrates by pulsed laser deposition. Results indicate that the preferentially oriented thin films exhibited a reversible capacity over $160 \mathrm{mAh} . \mathrm{g}^{-1}$ without any carbon or conducting additives (Rambabu, 2018).

\section{Solid-State Electrolytes}

In the commercial realization of all-solid-state Li-ion micro-batteries, the holygrail lies in development and implementation of solid-state electrolytes. Electrolytes work as a media for ionic mobility, allowing the chemical reactions to be completed at separate terminals to deliver energy to the external circuit. In case of liquid electrolytes, overcharging or short-circuiting can lead to high temperature resulting in fire or explosion (Robertson, 1997; Xu, 2006), creating chances of safety hazards. Numerous such accidents arising from liquid electrolytes have been reported worldwide involving portable electronics toairplanes. The safety limitations of liquid electrolytes restrict the development of electric vehicles (EVs) and large-scale grid-storage devices. To circumvent this safety issue, all-solid-state lithium batteries (ASSLiBs) have emerged as viable solution. ASSLiBs consist of cathode, anode and solid electrolyte obviating the need for liquid electrolyte. The solid electrolyte is the most critical component in all-solidstate thin film batteries. Efficient solid electrolyte materials should exhibit the following specifications.

1. It should have ionic conductivity higher than $10^{-7}{\mathrm{~S} . \mathrm{cm}^{-1}}$ at room temperature.

2. It should be chemically stable against metallic lithium and cathode materials.

3. It should have a high electrochemical decomposition voltage (higher than $5.5 \mathrm{~V}$ vs. $\mathrm{Li})$

4. It must have low toxicity.

5. It can be easily synthesized and fabricated (Thangadurai, 2005; Thangadurai, 2006).

6. It must carry as low cost, materials and productions as possible.

Some of the fundamental issues need to be cautioned for all-solid state thin film batteries

1. Volume and stress changes in materials during charge-discharge process, which effect the cycle life and safety.

2. Ion and electron migration between electrodes and electrolyte, which effects the specific capacity, specific power and cycle life.

3. Solid electrode/electrolyte interface, affecting the specific capacity and self-discharge.

From structural point-of-view, solid electrolytes are mainly classified into glassy and crystalline systems. Inthe last two decades, glassy lithium-ion conductors have been extensively studied as electrolytes for solid-state lithium-ion batteries due to several advantages such as: wide range selection of compositions, isotropic ion conduction and ease of fabrication as dense thin films along with minimal grain boundaries. These glassy lithium-ion conductors are further classified into two types based on the host materials: oxide glass and sulfide glass. Some principal 
solid electrolytes systems and their current status are briefly described below.

\section{Oxide Glass Electrolytes}

The oxide glass electrolytes are extensively studied due to their chemical/structural stability owing to less hygroscopic nature in comparison to sulfide glass electrolytes. In addition, oxide electrolytes do not react with electrode materials during (de)intercalation process, which is favorable to long cycling performance (Cho, 2006; Cho, 2007). Recently, Braga (2017) attempted a novel method of fabrication to make Li-S cell with glass electrolyte $\mathrm{A}_{2.99} \mathrm{Ba}_{0.005}$ $\mathrm{O}_{1+\mathrm{x}} \mathrm{Cl}_{1-2 \mathrm{x}}(\mathrm{A}=\mathrm{La}$ or $\mathrm{Na})$ having ionic conductivity $>$ $10^{-2} \mathrm{~S} \mathrm{~cm}{ }^{1}$. Cathode consists of plating the anode alkali-metal on a copper-carbon with $\mathrm{Na}$ or Li glassy electrolyte exhibited excellent properties, such as huge capacity giving a large energy density, long cycle life, low cost and especially safety which are suitable for friendly environmental large scale applications. This new approach of making solid-state battery made the researchers attention towards solid state batteries. Moreover, these electrolytes can be easily fabricated by physical vapor deposition methods especially in thin film form, which is beneficial for micro-battery application. The main disadvantage of these oxide glass electrolytes is low ionic conductivity. Extensive research has been focused to improve the ionic conductivity by selecting different compositions from binary systems such as $\mathrm{Li}_{2} \mathrm{O}-\mathrm{B}_{2} \mathrm{O}_{3}$ to ternary systems such as $\mathrm{Li}_{2} \mathrm{O}-\mathrm{SiO}_{2}-\mathrm{P}_{2} \mathrm{O}_{5}$. Among these thin film electrolytes, high $\mathrm{Li}^{+}$ionic conductivity has been obtained in twospecific material systems, namely $\mathrm{Li}_{2} \mathrm{O}$ $\mathrm{SiO}_{2}-\mathrm{V}_{2} \mathrm{O}_{5}$ (LVSO) and $\mathrm{Li}_{2} \mathrm{O}-\mathrm{P}_{2} \mathrm{O}_{5}-\mathrm{N}_{2}$ (LiPON), leading to their successful commercial application in micro-batteries.

\section{$\mathrm{Li}_{2} \mathrm{O}-\mathrm{SiO}_{2}-\mathrm{V}_{2} \mathrm{O}_{5}$ (LVSO) Thin Film Electrolytes}

The LVSO thin film electrolyte was deposited by Ohtsuka and Yamaki (Ohtsuka, 1989a; Ohtsuka, 1989b; Ohtsuka, 2001) using RF sputtering technique. The room temperature deposited amorphous film exhibited low ionic conductivity $\left(10^{-11} \mathrm{~S}_{\mathrm{cm}} \mathrm{cm}^{-1}\right)$ compared to the crystalline film $\left(10^{-10} \mathrm{~S} . \mathrm{cm}^{-1}\right)$. This might be due to the amorphous $\mathrm{Li}_{2} \mathrm{O}$ in the film that reacts with ambient $\mathrm{H}_{2} \mathrm{O}$ or $\mathrm{CO}_{2}$ forming $\mathrm{LiOH}$ or $\mathrm{Li}_{2} \mathrm{CO}_{3}$, thereby reducing the conductivity of the film. Ohtsuka et al. (Ohtsuka, 2001) fabricated microbatteries using LVSO as electrolyte with $\mathrm{MoO}_{3}$ thin film cathode and Li metal anode. The battery worked between $1.5-3.5 \mathrm{~V}$, delivering a discharge capacity of $60 \mu \mathrm{Ah} . \mathrm{cm}^{-2}$ with $1-\mu \mathrm{m}$ thickness cathode. Kawamura et al. (Kawamura, 2004) fabricated amorphous LVSO film by PLD with an ionic conductivity of about $10^{-7}$ ${\mathrm{S} . \mathrm{cm}^{-1}}^{-}$and an electronic conductivity of about $10^{-13}$ S. $\mathrm{cm}^{-1}$. The ionic conductivity of the LVSO amorphous films was lower than that of crystalline LVSO, probably due to the different degree of crystallinity and different compositions between the films and bulk material. Later, Kuwata et al. were the first to successfully demonstrate the fabrication of LVSO-based full cell micro-batteries $\left(\mathrm{LiCoO}_{2} \mid\right.$ LVSO $\mid \mathrm{SnO})$ and $\left(\mathrm{LiMn}_{2} \mathrm{O}_{4}|\mathrm{LVSO}| \mathrm{SnO}\right)$ by PLD technique (Kuwata, 2006).

\section{$\mathrm{Li}_{2} \mathrm{O}-\mathrm{P}_{2} \mathrm{O}_{5}-\mathrm{N}_{2}$ (LIPON) Thin Film Electrolytes}

The lithium phosphorous oxynitride thin film (LIPON) was first developed by Bates et al. (Bates, 1992) using RF sputtering with help of high purity $\mathrm{Li}_{3} \mathrm{PO}_{4}$ target in nitrogen atmosphere. Later, Yu et al. (Yu. 1997) observed that small amount of $\mathrm{N}$ incorporation can effectively stabilize the films with enhanced ionic conductivity. In the LIPON family, maximum ionic conductivity of $3.3 \times 10^{-6}{\mathrm{~S} . \mathrm{cm}^{-1}}^{\text {was observed for }}$ $\mathrm{Li}_{2.9} \mathrm{PO}_{3.3} \mathrm{~N}_{0.46}$ composition with activation energy of $0.55 \mathrm{eV}$ with negligible electronic conductivity. From above studies, it can be concluded that the high quality LIPON film can be prepared by RF sputtering. However, the rate of deposition is very low because of low pressure and low power required to avoid cracks of the target during deposition. Therefore, alternative techniques have been used to improve rate of deposition. Vereda et al. (Vereda, 2002) used an ion beam assisted technique to evaporate the $\mathrm{Li}_{3} \mathrm{PO}_{4}$ compound in $\mathrm{N}_{2}$ atmosphere to obtain LIPON films with faster growth rate, but the films appeared to creak due to large tensile stresses. PLD is another technique yielding high rate of deposition, but surface of the films was very rough, limiting its applications (Zhao, 2002). Kim et al. used Plasma-Assisted Directed Vapor Deposition (PA-DVD) to prepare LIPON thin films (Kim, 2008). The rate of deposition was extremely high compared to other techniques and the observed ionic conductivity was about $10^{-7} \mathrm{~S}_{\mathrm{cm}} \mathrm{cm}^{-1}$. They conclude that controlling the plasma conditions can improve the deposition rate and ionic conductivity without compromisingwith other electrolyte properties. Overall, LIPON thin filmswere found to 
be good electrolyte because of its high ionic conductivity, electronic resistivity and electrochemical stability with both metallic and metal oxide electrodes at cell potential up to $5.5 \mathrm{~V}$ (vs. Li). Subsequently, many all-solid-state micro-batteries have been developed implementing LIPON electrolytes delivering excellent electrochemical performance (Bates, 1996).

\section{Sulfide and Oxysulfide Glass Electrolytes}

The higher ionic conductivity of sulfide electrolytes has attracted significant attention to sulfide based systems. The thinfilm research on glassy sulfide was first studied by Kbala et al. (Kbala, 1984) focusing on $\mathrm{B}_{2} \mathrm{~S}_{3}-\mathrm{Li}_{2} \mathrm{~S}$ and $\mathrm{B}_{2} \mathrm{~S}_{3}-\mathrm{Li}_{2} \mathrm{~S}$-LiI sulfide systems. Interestingly, superior ionic conductivity $\left(10^{-3}-10^{-4}\right.$ S.cm ${ }^{-1}$ ) was observed in sulfide systemsin comparison to the oxide glassy electrolytes. This may be due to the presence of LiI in the ternary system. Later, Creus et al. (Creus, 1989) used vacuum evaporation technique to prepare thin film of $\mathrm{Li}_{2} \mathrm{~S}-\mathrm{SiS}_{2}$ binary glass and its ternary derivative $\mathrm{Li}_{2} \mathrm{~S}_{-} \mathrm{SiS}_{2}-\mathrm{P}_{2} \mathrm{~S}_{5}$. They found that cell resistance is very large due to the electrolyte reactivity with lithium metal and forming a resistance layer. This resistance layer can be avoided by using a LiI protective layer as proposed by Creus et al. (Creus, 1989). With this idea, Eveready Battery Company (USA) developed $\mathrm{Li}^{-\mathrm{TiS}_{2}}$ thin film batteries with outstanding performance. These micro-batteries were cycled more than 1000 cycles between 1.4-2.8 $\mathrm{V}$ with over $90 \%$ of cathode utilization. The thin films of $\mathrm{Li}_{2} \mathrm{~S}-\mathrm{GeS}_{2}-\mathrm{Ga}_{2} \mathrm{~S}_{3}$ glass system prepared by RFsputtering were reported by Yamashita et al. (Yamashita, 1996; 2003). The ionic conductivity was almost identical to that of bulk glasses with similar compositions, which increases with higher $\mathrm{Li}_{2} \mathrm{~S}$ content. The film had an ionic conductivity of about $1.4 \times 10^{-4}{\mathrm{~S} . \mathrm{cm}^{-1}}^{-}$at room temperature with the highest lithium content. Despite having high ionic conductivity, unfortunately glassy sulfides have not been used widely in micro-batteries due to the chemical corrosion and hygroscopic nature.

\section{Crystalline Electrolytes}

Generally speaking, crystalline materials should have higher ionic conductivity and better stability over the corresponding glasses if their crystal structures have been well designed for high ionic conduction. However, it is not the case with crystalline lithium ionic conductors whose ionic conductivities and electrochemical decomposition potentials are usually lower than glassy materials (Xia, 2009). The sole advantage of crystalline lithium ion conductors is their high temperature stability. Therefore, a fully crystalline, high temperature-annealed electrolyte is appealing for solid-state systems, where a high-temperature process step is desirable for cathode improvement and enhancement of electrode/electrolyte interfacial quality. There is a constant search for new crystalline lithium-ion conductors. Some compounds have been found with promising $\mathrm{Li}^{+}$ionic conductivity at room temperature and possible use as thin film electrolyte for micro-batteries.

\section{NASICON-type Electrolytes}

The schematic crystal structure of NASICON-type compound is shown in Fig. 5. Various NASICON type compounds with general formula $\mathrm{LiM}^{\mathrm{IV}}{ }_{2}\left(\mathrm{PO}_{4}\right)_{3}\left(\mathrm{M}^{\mathrm{IV}}\right.$ $=\mathrm{Ti}, \mathrm{Zr}, \mathrm{Hf}, \mathrm{Ge}, \mathrm{Sn}$ and etc. $)$ or $\mathrm{LiM}^{\mathrm{V}} \mathrm{M}^{\mathrm{III}}\left(\mathrm{PO}_{4}\right)_{3}\left(\mathrm{M}^{\mathrm{V}}\right.$ $=\mathrm{Nb}, \mathrm{Ta}, \mathrm{Sb}$, and $\mathrm{V}$ and $\mathrm{M}^{\mathrm{III}}=\mathrm{Al}, \mathrm{Cr}$ and $\mathrm{Fe}$ ) have been reported (Goodenough, 1976; Bates, 2000). The main advantages of these compounds are their high ionic conductivity, high temperature stability, low thermal expansion behavior and large surface area. Brike et al. successfully fabricated the first all-solidstate thin film battery $\left(\mathrm{LiMn}_{2} \mathrm{O}_{4}\left|\mathrm{Li}_{1.3} \mathrm{Al}_{0.3} \mathrm{Ti}_{1.7}\left(\mathrm{PO}_{4}\right)_{3}\right|\right.$ $\mathrm{Li}_{4} \mathrm{Ti}_{5} \mathrm{O}_{12}$ ) (Birke, 1999). $\mathrm{Li}_{4} \mathrm{Ti}_{5} \mathrm{O}_{12}$ anode was used to overcome the instability between lithium metal and $\mathrm{Ti}^{4+}$ containing NASICON electrolyte and $\mathrm{LiBO}_{2} \cdot \mathrm{LiF}$ was added to block undesired reactions between electrodes and electrolyte. The thin films of $\mathrm{Li}_{4} \mathrm{Ti}_{5} \mathrm{O}_{12}$ and $\mathrm{LiMn}_{2} \mathrm{O}_{4}$ spinels were prepared on $\mathrm{Li}_{1+\mathrm{x}} \mathrm{Ti}_{2-}$ ${ }_{x} \mathrm{Al}_{\mathrm{x}}\left(\mathrm{PO}_{4}\right)_{3}$ (LTP) electrolyte by sol-gel method (Hoshina, 2005; Dokko, 2007). The interface between electrodes and electrolyte was studied by fabricating the all-solid-state battery $\mathrm{Li}_{4} \mathrm{Ti}_{5} \mathrm{O}_{12}\left(\right.$ or $\left.\mathrm{LiMn}_{2} \mathrm{O}_{4}\right) \mid$ LTP | PMMA | Li, where PMMA is poly (methylmethacrylate) to avoid direct contact between LTP and lithium metal. It was found that the battery performance was mainly controlled by the electrode/ electrolyte contact and the sol-gel coated thin films led to porous morphology with rough surface that induced poor electrode-electrolyte contact. Wu et al. $(\mathrm{Wu}, 2003)$ investigated $\mathrm{Li}_{1.3} \mathrm{Al}_{0.3} \mathrm{Ti}_{1.7}\left(\mathrm{PO}_{4}\right)_{3}$ NASICON thin films prepared by the sol-gel spinning method with post annealing between $750-900^{\circ} \mathrm{C}$. Films annealed at $800^{\circ} \mathrm{C}$ exhibited an ionic conductivity of $1.5 \times 10^{-5}{\mathrm{~S} . \mathrm{cm}^{-1}}$ and electronic conductivity of 

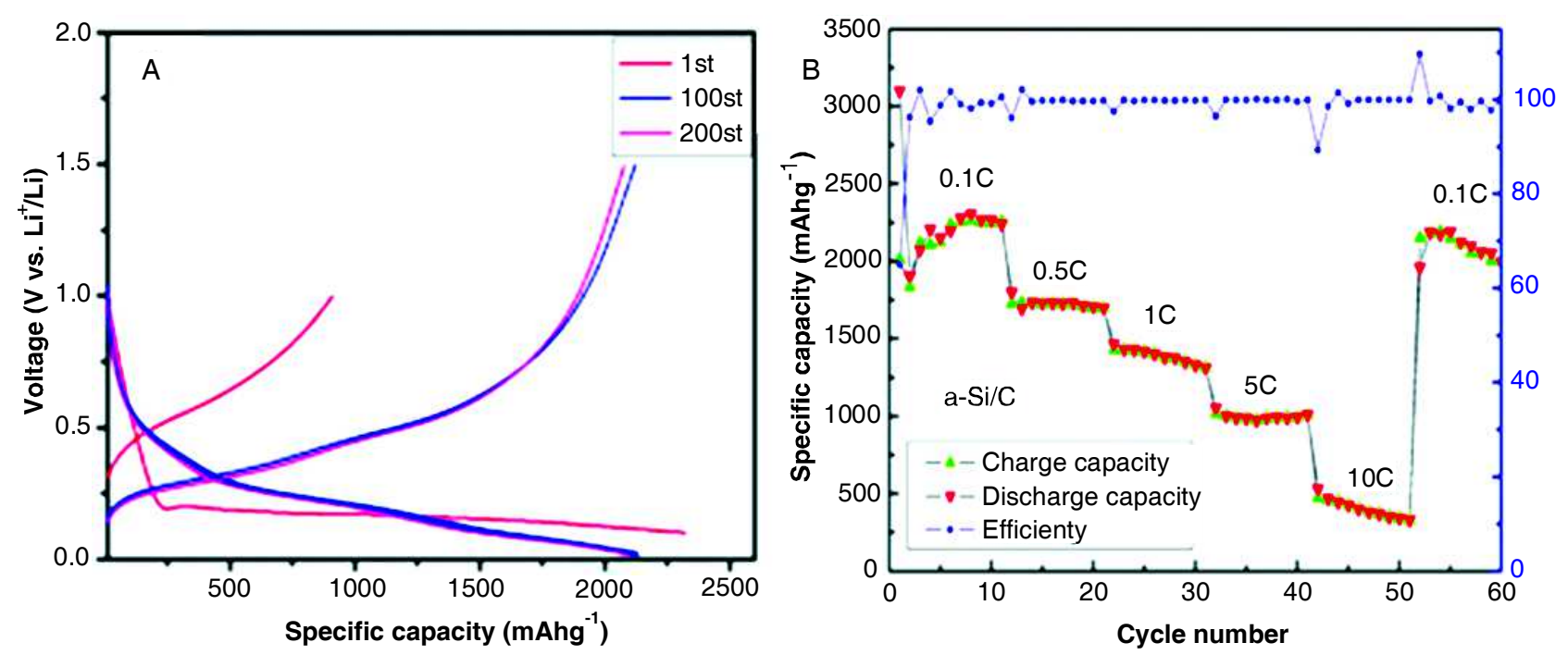

Fig. 5: (A) Charge- discharge curves of $\mathrm{Si} / \mathrm{C}$ multilayer thin films (B) rate capability and coulombic efficiency of $\mathrm{Si} / \mathrm{C}$ films. Reproduced from reference (Tong, 2014)

$5 \times 10^{-11}{\mathrm{~S} . \mathrm{cm}^{-1}}^{-}$Overall, NASICON systems form a robust family to design highly conducting solidelectrolyte for thin film batteries.

\section{LISICON-type Electrolytes}

The LISICON (lithium super ionic conductor) type $\mathrm{Li}_{4 \pm \mathrm{x}} \mathrm{Si}_{1-\mathrm{x}} \mathrm{X}_{\mathrm{x}} \mathrm{O}_{4}(\mathrm{X}=\mathrm{P}, \mathrm{Al}$, or $\mathrm{Ge})$ compounds are attracted much as a solid-state electrolytes for all solidstate batteries because of its high lithium ionic conductivity. The first material given the name LISICON was $\mathrm{Li}_{3.5} \mathrm{Zn}_{0.25} \mathrm{GeO}_{4}$ (Robertson, 1997). Whitacre (2004) fabricated the all solid-state thin film battery by depositing $\mathrm{Li}$ film and $\mathrm{LiCoO}_{2}$ films on each side of the of a crystalline $\mathrm{Li}_{3} \mathrm{PO}_{4} / \mathrm{Li}_{4} \mathrm{SiO}_{4}$ electrolyte chip. Cathode crystallization was done by annealing at $700^{\circ} \mathrm{C}$. Results revealed that annealing at high temperature is not affecting on full cell performance. Solid-state full cell works well without induce any interfacial defects between electrode and electrolyte. Therefore, fabrication all-solid-state thin films batteries with crystalline LISICON thin film is recommended for further developments in battery technology.

Apart from oxide compounds, sulphide compounds with LISICON type structure have been developed and are named as thio-LISICON. The compounds of $\mathrm{Li}_{2} \mathrm{~S}-\mathrm{GeS}_{2}, \mathrm{Li}_{2} \mathrm{~S}-\mathrm{GeS}_{2}-\mathrm{ZnS}, \mathrm{Li}_{2} \mathrm{~S}-\mathrm{GeS}_{2}$ $\mathrm{Ga}_{2} \mathrm{~S}_{3}$, and $\mathrm{Li}_{2} \mathrm{~S}-\mathrm{GeS}_{2}-\mathrm{P}_{2} \mathrm{~S}_{5}$ systems have the structures related to the $\gamma-\mathrm{Li}_{3} \mathrm{PO}_{4}$ type (Kanno, 2001). The new bulk compound of $\mathrm{Li}_{10} \mathrm{GeP}_{2} \mathrm{~S}_{12}$ exhibited extremely high ionic conductivity of $1.2 \times 10^{-2} \mathrm{~S}_{\mathrm{cm}} \mathrm{cm}^{-1}$
(Kamaya, 2011). Ohta (2005) fabricated the $\mathrm{Li}_{3.25} \mathrm{Ge}_{0.25} \mathrm{P}_{0.75} \mathrm{~S}_{4}$ thin films on the sapphire substrates using pulsed laser deposition. The observed lithium ionic conductivity is about $1.7 \times 10^{-4} \mathrm{~S}_{\mathrm{cm}} \mathrm{cm}^{-1}$ that was one-fifth of the bulk material. The decrease in ionic conductivity in thin film was related to the increased lithium content leading to reduction in the number of lithium vacancies in the LISICON structure. However, the thio-LISICON material exhibited promising ionic conductivity at room temperature along with good electronic conductivity and electrochemical stability. All-solid-state thin film battery of these compounds warrants elaborate study.

\section{Perovskite Electrolytes}

Perovskite family of compounds form a potential family to design polycrystalline solid electrolyte because of their high ionic conductivity. The crystal structure of perovskite with general formula $\mathrm{ABO}_{3}$ is shown in Fig. 6. Stramare et al. (Stramare, 2003) observed that the $\mathrm{ABO}_{3}$-type lithium lanthanum titanates (LLTO) $\mathrm{La}_{2 / 3-\mathrm{x}} \mathrm{Li}_{3 \mathrm{x}} \mathrm{TiO}_{3}(\mathrm{La}, \mathrm{Li}$ at A site, and $\mathrm{Ti}$ at $\mathrm{B}$ site) exhibited high ionic conductivity with its three-dimensional framework built from cornersharing $\mathrm{TiO}_{6}$ octahedra with alternative stacks of Larich and $\mathrm{La}$-deficit sites along c-axis. Although, having high ionic conductivity, it was not used as electrolyte due to its lack of stability when in contact with the electrodes. The first thin film work on perovskitetype materials was reported by Kitaoka et al. 
(Kitaoka, 1997). They measured the ionic conductivity of LLTO thin films prepared by sol-gel process around $10^{-7} \mathrm{~S} . \mathrm{cm}^{-1}$ that is less than the conductivity of bulk materials. Lee et al. prepared LLTO thin films by RF-sputtering, but they failed to fabricate high quality thin films (Lee, 2006). Later, LLTO thin film was successfully prepared by pulsed laser deposition exhibiting high ionic conductivity value of $8.2 \times 10^{-4}$ S.cm ${ }^{-1}$ similar to the bulk material (Maqueda, 2008). Further, Ahnand Yoon found that amorphous LLTO thin films exhibited better electrochemical properties than crystalline LLTO films (Ahn, 2005). Various perovskite structured compounds can be unveiled for practical application/s in all-solid-state micro-batteries.

\section{Garnet Type Electrolytes}

Recently, oxides with garnet related structures have received great attention as a potential solid-state electrolyte for LIBs. The typical structure of garnets is $\mathrm{A}_{3} \mathrm{~B}_{2} \mathrm{C}_{3} \mathrm{O}_{12}$ with $\mathrm{CO}_{4}$ tetrahedra and $\mathrm{BO}_{6}$ octahedra that are connected via edge sharing fashion (Murugan, 2007). Although this is the general formula, it has been reported that increasing the number of lithium per formula unit from 5-7 results in increase of ionic conductivity 3-5 orders of magnitude. For example, $\mathrm{Li}_{7} \mathrm{La}_{3} \mathrm{Zr}_{2} \mathrm{O}_{12}$ (LLZO) exhibited a highest ionic conductivity approximately $2 \times 10^{-4} \mathrm{~S}^{-\mathrm{cm}^{-1}}$ at room temperature with good thermal stability against lithium metal, air, and moisture (Masashi, 2010). The unique properties of garnet type structures are attracted wide research interest for further developments in soldstate electrolytes. Thin film research on this material is encouraged to explore the possibility of their use in thin film electrolyte for micro-batteries. The amorphous LLZO thin films are successfully deposited using RF magnetron sputtering. It was observed that films deposited at low RF power (40 W) exhibited the highest ionic conductivity $\left(4 \times 10^{-7}\right.$ $\mathrm{Scm}^{-1}$ ) due higher concentration of $\mathrm{Li}_{2} \mathrm{O}$ (Kalita, 2012). Epitaxial growth of Al- doped LLZO thin films was realized by using pulsed laser deposition. The ionic conductivities in the grains of (001) and (111) films were $2.5 \times 10^{-6}$ and $1.0 \times 10^{-5} \mathrm{~S}^{-\mathrm{cm}^{-1}}$. It revealed that the decrease in conductivity due to (a) $\mathrm{Al}^{3+}$ substitution in the LLZO lattice decreases the number of movable lithium ions and blocks the threedimensional lithium migration pathway (b) lattice mismatch between substrate and film which led to lattice distortion of LLZO film (Sangryun, 2013).
Later, Al-doped LLZO thin films were prepared using sol-gel method. Polycrystalline cubic structured LLZO films were obtained during the heat treatment at $900^{\circ} \mathrm{C}$ having an ionic conductivity of $2.4 \times 10^{-6}$ S.cm ${ }^{-1}$ at $25^{\circ} \mathrm{C}$ (Kiyoharu, 2015). The typical crystal structure of NASICION, LiPON, Perovskite and Garnet are shown in Fig. 6.

\section{Summary and Perspectives}

In summary, there has been great interest in research and understanding of all-solid-state thin film microbatteries because of their potential applications, ranging from micro-electronics to (plug-in) hybrid electric vehicles. The all-solid-state-batteries have an ideal combination of high electrochemical energy/ power density, cycling stability along with robust operational safety. Nanostructured thin film materials offer tunable features based on the particle size, morphology and chemical composition. The advantages of thin film batteries such as high purity, perfect composition and free from conductive additives or carbon coating have driven the researchers to explore the intrinsic properties of thin film electrodes and electrolytes. Thin-film technology provides (a) clean surface of the compound and improve the electrode-electrolyte interface contact reducing the interface resistance and permitting a high reversibility, (b) deposition in vacuum avoids possible moisture problems, (c) generally gives very good adhesion between layers and large areas can also be obtained which leads to minimize the self-discharge rate in thin films and improve the overall battery performance. In the current article, various well-known family of cathodes, anodes and solid electrolytes were reviewed with special focus on solid-electrolytes. Over the last three decades, there has been significant improvement in solid-state battery research with performance inching close to that of conventional batteries.

The future demand for cost effective and miniaturized electronic devices can be served with implementation of all-solid-state thin film microbatteries.In this sector, various processing techniques such as pulsed laser deposition (PLD) and RF Sputtering can be employed to fabricate thin films with desired shape/size, light weight, multilayer formation having corrosion resistance and thermal stability. The design and architecture of all-solid-state thin film batteries is quite different from traditional 

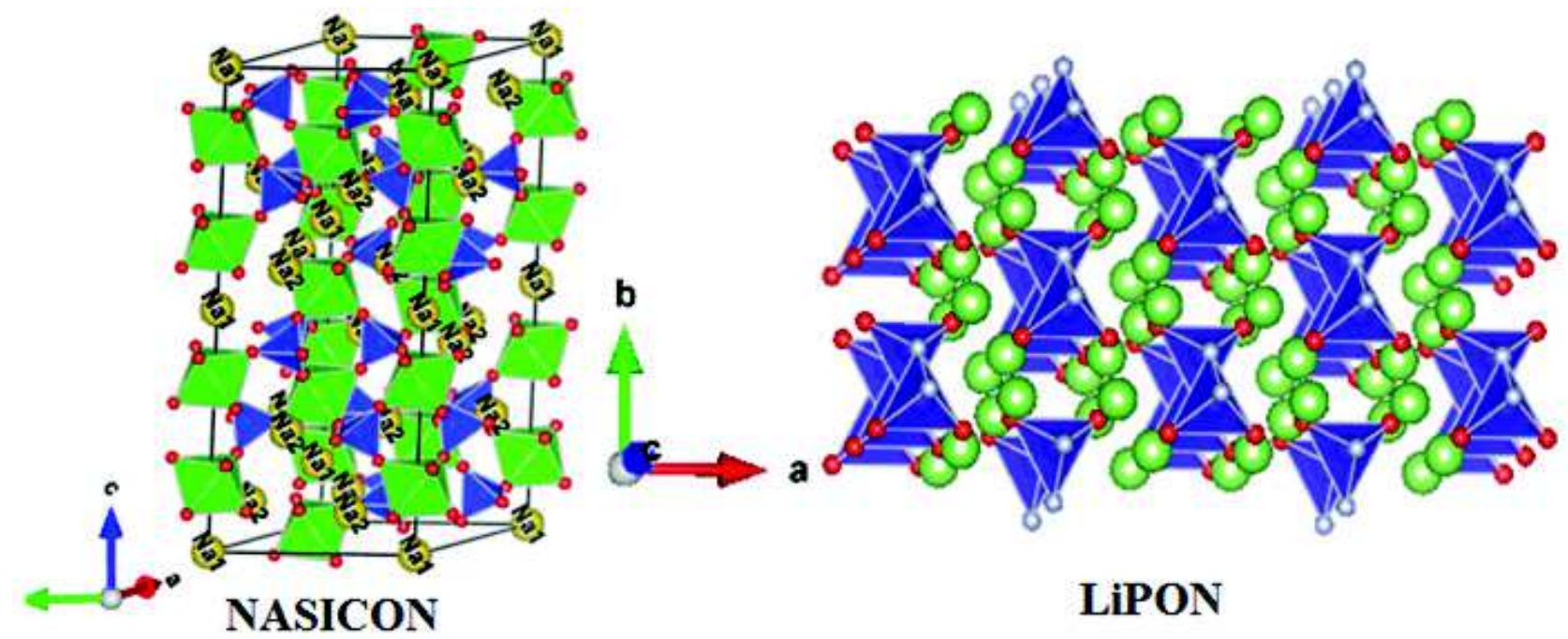

\section{NASICON}
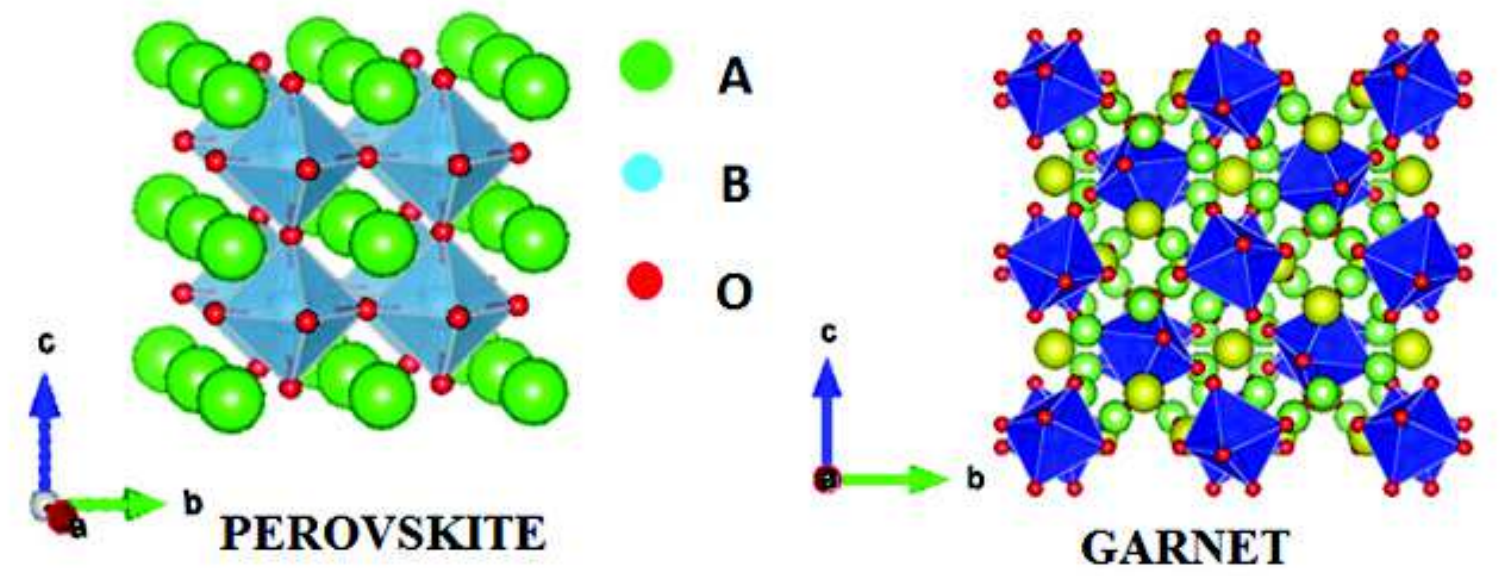

Fig. 6: Schematic crystal structures of NASICON, LiPON, Perovskite and Garnet type electrolytes

batteries using liquid (organic) electrolytes. The most difficult challenge in fabricating all-solid-state batteries is to assure intimate and uniform contact between electrode and solid electrolyte interface. Additionally, it is an uphill task to match the $\mathrm{Li}^{+}$ionic conductivity of solid-electrolyte to that of currently used liquid electrolytes.It calls for multi-disciplinary material and process innovation targeting (i) novel low cost and energy-dense electrode materials and (ii) unraveling novel solid electrolyte materials having an ideal combination of superior ionic conductivity along with material/thermal stability. Future research efforts also need to be geared toward addressing some fundamental challenges such as electrode-electrolyte degradation owing to microstructural change, low cost processing enabling uniform electrode/electrolyte interfacial contactand upscaling of micro-batteries fabrication for commercial viability. With these research pursuits, the world is on the verge of yet another battery revolution with large-scale dissemination of all-solid-state batteries. Propelling suites of small-scale micro-electronics/gadgets to large-scale (hybrid) electric vehicles.

\section{Acknowledgements}

AR is thankful to the University Grants Commission (UGC) for a postdoctoral fellowship at IISc. SBK is grateful to the Science and Engineering Research Board (SERB) for a J. C. Bose Fellowship. PB thanks the Board of Research on Nuclear Sciences (BRNS, Department of Atomic Energy) for a DAE-BRNS Young Scientist Research Award (YSRA). The authors acknowledge the financial support from ISROIISc Space Technology Cell (ISTC/CMR/PB/396). 


\section{References}

Ahn J-K and Yoon S-G (2005) Characteristics of Amorphous Lithium Lanthanum Titanate Electrolyte Thin Films Grown by PLD for Use in Rechargeable Lithium Microbatteries Electroche. \& Solid-State Letters 8(2) A75A78

Alexis B, Béléké, Faure C, Röder M, Hovington P, Posset H, Guerfi A and Zaghi K (2016) Chemically fabricated $\mathrm{LiFePO}_{4}$ thin film electrode for transparent batteries and electrochromic devices Materials Science and Engineering B 214 81-86

Baba M (1999) Fabrication and electrochemical characteristics of all- solid-state lithium-ion batteries using $\mathrm{V}_{2} \mathrm{O}_{5}$ thin films for both electrodes Electrochemical and Solid State Letters 2(7) p.p 320-322, 1099-0062

Baba M, Kumagai N, Fujita N, Ohta K, Nishidate K and Komaba S (2001) Fabrication and electrochemical characteristics of all-solid-state lithium-ion rechargeable batteries composed of $\mathrm{LiMn}_{2} \mathrm{O}_{4}$ positive and $\mathrm{V}_{2} \mathrm{O}_{5}$ negative electrodes Journal of Power Sources 97-98 pp. 798-800, 0378-7753

Baba M, Kumagai N, Fujita H, Ohta K, Nishidate K, Komaba S, Kaplan B, Groult H and Devilliers D (2003) Multi-layered Li-ion rechargeable batteries for a high-voltage and highcurrent solid-state power source J Power Sources 119 914-917

Baba M, Kumagai N, Fujita N, Ohta K, Nishidate k, Komaba K, Groult H, Devilliers D and Kaplan B (2001) Fabrication and electrochemical characteristics of all-solid-state lithium-ion rechargeable batteries composed of $\mathrm{LiMn}_{2} \mathrm{O}_{4}$ positive and $\mathrm{V}_{2} \mathrm{O}_{5}$ negative electrodes $J$ Power Sources 97 798-800

Baba M, Kumagai N, Fujita H, Ohta K, Nishidate K, Komaba S, Kaplan D, Groult H and Devilliers D (2003) Multi-layered Li-ion rechargeable batteries for a high-voltage and highcurrent solid-state power source J Power Sources 119 914-917

Baba M, Kumagai N, Kobayashi H, Nakano O and Nishidate K (1999) Fabrication and Electrochemical Characteristics of All Solid State Lithium Ion Batteries Using $\mathrm{V}_{2} \mathrm{O}_{5}$ Thin Films for Both Electrodes Electrochem Solid-state Letters 2 320-322

Bajars G, Kucinskis G, Smits J and Kleperis J (2011) Physical and electrochemical properties of $\mathrm{LiFePO}_{4} / \mathrm{C}$ thin films deposited by direct current and radiofrequency magnetron sputtering Solid State Ionics 188 156-159

Bao Q, Chen C, Wang D, Ji Q and Lei I (2005) Pulsed laser deposition and its current research status in preparing hydroxyapatite thin films Applied Surface Science $\mathbf{2 5 2}$ pp. $1538-1544,0169-4332$

Baskaran R, Kuwata N, Kamishima O, Kawamura J and Selvasekarapandian S (2009) Structural and electrochemical studies on thin film $\mathrm{LiNi}_{0.8} \mathrm{Co}_{0.2} \mathrm{O}_{2}$ by PLD for micro battery Solid State Ionics 180 636-643

Bates J B, Dudney N J, Neudecker B and Evans C D (2000) Thin-film lithium and lithium-ion batteries Solid State Ionics $13533-45$

Bates J B, Dudney N J, Gruzalski G R, Zuhr R A, Choudhury A and Robertson J D (1993) Fabrication and characterization of amorphous lithium electrolyte thin films and rechargeable thin-film batteries Journal of Power Sources 43 pp. 103$110,0378-7753$

Bates J B, Dudney N J, Gruzalski G R, Zuhr R A, Choudhury A, Luck C F and Robertson J D (1993) Fabrication and characterization of amorphous lithium electrolyte thin films and rechargeable thin-film batteries $J$ Power Sources 43 103-110

Bates J B, Dudney N J, Ueda A and Evans C D (2000) Thin-film lithium and lithium-ion batteries Solid State Ionics 13533 45

Bates J B, Dudney N J, Gruzalski G R, Zuhr R A, Choudhury A and Luck C F (1992) Electrical properties of amorphous lithium electrolyte thin films Solid State Ionics 53-56 647654

Bates J B and Yu X (1996) Enhanced deposition rate of lithium phosphorus oxynitride thin films by sputtering of $\mathrm{Li}_{3} \mathrm{PO}_{4}$ in $\mathrm{N}_{2}$-He gas mixtures Jour Vac Sci and Tech A 14 34-37

Bates J B, Dudney N J, Neudecker N, Ueda A and Evans C D (2000) Thin-film lithium and lithium-ion batteries Solid State Ionics 135 pp. 33-45, 0167-2738

Bates J B, Lubben D, Dudney N J and Hart F X (1995) 5-Volt Plateau in $\mathrm{LiMn}_{2} \mathrm{O}_{4}$ Thin Films $J$ Electrochem Soc 142 L149-L151

Birke P, Salam F, Doring S and Weppner W (1999) A first approach to a monolithic all solid state inorganic lithium battery Solid State Ionics 118 149-157

Braga M H, Grundish N S, Murchison A J and Goodenough J B (2017) Alternative strategy for a safe rechargeable battery Energy Environ Sci 10 331-336

Bruce P G (1997) Solid-state chemistry of lithium power sources Chem Commun 19 1817-1824

Choi M, Lee S-H, Yang-Il Jung, Jung J-Y, Park Y-S and Choi W$\mathrm{K}$ (2017) The high capacity and cycle stability of $\mathrm{NiFe}_{2} \mathrm{O}_{4}$ thin film prepared by E-beam evaporation method for lithium ion batteries $J$ Alloys and Compounds 729 802808 
Cho K I, Lee S H, Cho K H, Shin D W and Sun Y K (2006) $\mathrm{Li}_{2} \mathrm{O}-$ $\mathrm{B}_{2} \mathrm{O}_{3}-\mathrm{P}_{2} \mathrm{O}_{5}$ solid electrolyte for thin film batteries Journal of Power Sources 163 223-228

Cho K, Lee T, Oh J and Shin D (2007) Fabrication of $\mathrm{Li}_{2} \mathrm{O}-\mathrm{B}_{2} \mathrm{O}_{3}-$ $\mathrm{P}_{2} \mathrm{O}_{5}$ solid electrolyte by aerosol flame deposition for thin film batteries Solid State Ionics 178 119-123

Chrisey D and Hubler G K (1994) vol. 154-155 (Wiley, New York)

Creus R, Sarradin J, Astier R, Pradel A and Ribes M (1989) The use of ionic and mixed conductive glasses in microbatteries Materials Science and Engineering B 3 109-112

Danmei Y, Yajuan Q, Xiaoyuan Z, Jie W, Chao L, Changguo C and Qisheng H (2014) Mica-like vanadium pentoxidenanostructured thin film as high-performance cathode for lithium-ion batteries Journal of Power Sources 266 1-6

Ding J-J, Sun Q and Fu Z-W (2010) Layered Li $\quad\left(\mathrm{Ni}_{1}\right.$ $\left.{ }_{4} \mathrm{MnCo}_{13}\right) \mathrm{O}_{2}$ as Cathode Material for All-Solid-State ThinFilm Rechargeable Lithium-Ion Batteries Electrochem. Solid-state Lett 13 A105-A108

Dokko K, Hoshina K, Nakano H and Kanamura K (2007) Preparation of $\mathrm{LiMn}_{2} \mathrm{O}_{4}$ thin-film electrode on $\mathrm{Li}_{1+\mathrm{x}} \mathrm{Al}_{\mathrm{x}} \mathrm{Ti}_{2 " \mathrm{x}}\left(\mathrm{PO}_{4}\right)_{3}$ NASICON-type solid electrolyte Journal of Power Sources 174 1100-1103

Dudney N J, Bates J B, Zuhr R A, Young S, Robertson J D, Juncan H P and Hackney (1999) Nanocrystalline $\mathrm{Li}_{\mathrm{x}} \mathrm{Mn}_{2 \mathrm{y}} \mathrm{O}_{4}$ Cathodes for Solid State Thin Film Rechargeable Lithium Batteries Journal of the Electrochemical Society 146 pp. 2455-2464, 0013-4651

Dudney N J, Bates J B, Zuhr R A, Young S, Robertson J D, Jun H P and Hackney S A (1999) Nanocrystalline $\mathrm{Li}_{x} \mathrm{Mn}_{2-y} \mathrm{O}_{4}$ cathodes for solid-state thin-film rechargeable lithium batteries Journal of the Electrochemical Society 1462455 2464, 0013-4651

Eun J J, Young W S, Sang C N, Won C and Young S S (2001) Characterization of All-Solid-State Thin-Film Batteries with $\mathrm{V}_{2} \mathrm{O}_{5}$ Thin-Film Cathodes Using ex situ and in situ Processes J Electrochem Soc 148 A318-A322

Fujimoto D, Kuwata N, Matsuda Y and Kawamura J (2015) Fabrication of solid-state thin-film batteries using $\mathrm{LiMnPO}_{4}$ thin films deposited by pulsed laser deposition Thin Solid Films 579 81-88

Glenneberg J, Andre F, Bardenhagen I, Langer F, Schwenzel J and Kun R (2016) A concept for direct deposition of thin film batteries on flexible polymer substrate Journal of Power Sources 324 722-728

Gong C, Ruzmetov D, Pearse A, Ma D, Jeremy N-M, Rubloff G, Talin AA, and Leite M S (2015) Surface/Interface Effects on High-Performance Thin-Film All-Solid-State Li-Ion
Batteries ACS Appl Mater Interfaces 7 26007-26011

Goodenough J B, Hong H P-Y and Kafalas J A (1976) Fast Na ${ }^{+}$ ion transport in skeleton structures Mater Res Bull $\mathbf{1 1}$ 203-220

Hayashi M, Takahashi M and Sakurai Y (2007) Preparation of positive $\mathrm{LiCoO}_{2}$ films by electron cyclotron resonance (ECR) plasma sputtering method and its application to all-solid-state thin-film lithium batteries J Power Sources 174 990-995

Hoshina N, Dokko K and Kanamura K (2005) Investigation on Electrochemical Interface between $\mathrm{Li}_{4} \mathrm{Ti}_{5} \mathrm{O}_{12}$ and $\mathrm{Li}_{1+\mathrm{x}} \mathrm{Al}_{\mathrm{x}} \mathrm{Ti}_{2 " \mathrm{x}}\left(\mathrm{PO}_{4}\right)_{3}$ NASICON-Type Solid Electrolyte Journal of the Electrochemical Society 152 A2138-A2142

Iriyama Y, Yokoyama M, Yada C, Jeong S K, Yamada I, Abe T, Inaba $\mathrm{M}$ and Ogumi Z (2004) Preparation of LiFePO4 Thin Films by Pulsed Laser Deposition and Their Electrochemical Properties Electrochem Solid-state Lett 7 A340-A342

James R A and H Vourlis (1988) Performance of Li/TiS2 solid state batteries using phosphorous chalcogenide network former glasses as solid electrolyte Solid State Ionics 28-30 pp. 841-846, 0167-2738

Jacke S, Song J, Cherkashinin G, Dimesso L and Jaegermann W (2010) Investigation of the solid-state electrolyte/cathode $\mathrm{LiPON} / \mathrm{LiCoO}_{2}$ interface by photoelectron spectroscopy Ionics 16 769-775

Jang Y, Dudney N J and Allard L F (2002) High-Voltage Cycling Behavior of Thin-Film $\mathrm{LiCoO}_{2}$ Cathodes $J$ Electrochem Soc 149 A1442-A1447

Jones S D and Akridge J R (1992) thin film solid state microbattery Solid State Ionics $\mathbf{5 3}$ 628-634

Jones S D, Akridge J R and Shokoohi F K (1994) Thin film rechargeable Li batteries Solid State Ionics 69 357-368

Jourdaine L, Souquet J L, Delord V and Ribes M (1988) Lithium solid state glass-based microgenerators Solid State Ionics 28 1490-1494

Kaczmarek S (1996) Pulsed laser deposition - Today and tomorrow: Laser Technology V Applications in Mater Sciences and Engg 3187 129-134

Kalita D J, Lee S H, Lee K S, Ko D H and Yoon Y S (2012) Ionic conductivity properties of amorphous Li-La-Zr-O solid electrolyte for thin film batteries Solid State Ionics 229 1419

Kanehori K (1986) Titanium Disulfide Films Fabricated by Plasma CVD Solid State Ionics 18-19 pp. 818-822, 0167-2738

Kanehori K, Matsumoto K, Miyauchi K and Kudo T (1983) Thin film solid electrolyte and its applications to secondary 
lithium cell Solid State Ionics 9 1445-1448

Kanehori K, Matsumoto K, Miyauchi K and Kudo T (1986) Titanium disulphide films fabricated by plasma CVD Solid State Ionics 18 818-822

Kawamura J, Kuwata N, Toribami K, Sata N, Kamishima O and Hattori T (2004) Preparation of amorphous lithium ion conductor thin films by pulsed laser deposition Solid State Ionics 175 273-276

Kbala M, Makyta M, Levasseur M A and Hagenmuller P (1984) Characterization and electrical behavior of new lithium chalcoborate thin films Solid State Ionics 15 163-169

Kim H-K, Seong T-Y, Cho W-I and Yoon Y S (2002) Rapid thermal annealing effect on surface of $\mathrm{LiNi}_{1 " \mathrm{x}} \mathrm{Co}_{\mathrm{x}} \mathrm{O}_{2}$ cathode film for thin-film microbattery $J$ Power Sources 109178 183

Kim H-K, Seong T-Y and Yoon Y S (2002) Fabrication of a Thin Film Battery Using a Rapid-Thermal-Annealed $\mathrm{LiNiO}_{2}$ Cathode Electrochem Solid-state Lett 5 A252-A255

Kim Y G and Wadley H N G (2008) Lithium phosphorous oxynitride films synthesized by a plasma-assisted directed vapor deposition approach Journal of Vacuum Science and Technology A 26 174-183

Kirino F, Ito Y, Miyauchi K and Kudo T (1986) Electrochemical Behavior of Amorphous Thin Films of Sputtered $\mathrm{V}_{2} \mathrm{O}_{5}-$ $\mathrm{WO}_{3}$ Mixed Conductors Nippon Kagaku Kaishi 3 445450

Kitaoka K, Hashimoto T and Yoko T (1997) Preparation of $\mathrm{La}_{0.5} \mathrm{Li}_{0.5} \mathrm{TiO}_{3}$ perovskite thin films by the sol-gel method Journal of Materials Science 32 2063-2070

Kitaura H, Takahashi K, Mizuno F, Hayashi A, Tadanaga K and Tatsumisago M (2007) Preparation of á- $\mathrm{Fe}_{2} \mathrm{O}_{3}$ Electrode Materials via Solution Process and Their Electrochemical Properties in All-Solid-State Lithium Batteries $J$ Electrochem Soc 154 A725-A729

Kiyoharu T, Hiromi E, Akitoshi H, Masahiro T, Jadra M, Mario A and Alicia D (2015) Preparation of lithium ion conductive Al-doped $\mathrm{Li}_{7} \mathrm{La}_{3} \mathrm{Zr}_{2} \mathrm{O}_{12}$ thin films by a sol-gel process Journal of Power Sources 273 844-847

Kotobuki M, Munakata H and Kanamura K (2013) Chapter 4.2, Handbook of Advanced Ceramics, second ed., Academic Press, Oxford, 343-351

Kun R, Schlee P, Pal E, Busse M and Gesing T (2017) Role of the precursor chemistry on the phase composition and electrochemical performance of thin-film $\mathrm{LiMn}_{2} \mathrm{O}_{4} \mathrm{Li}$-ion battery cathodes prepared by spray pyrolysis Journal of Alloys and Compounds $\mathbf{7 2 6}$ 664-674

Kuwata N, Kumar R, Toribami K, Suzuki T, Hattori T and
Kawamura J (2006) Thin film lithium ion batteries prepared only by pulsed laser deposition Solid State Ionics 1772827 2832.

Kuwata N, Iwagami N, Tanji Y, Matsuda Y and Kawamura J (2010) Characterization of Thin-Film Lithium Batteries with Stable Thin-Film $\mathrm{Li}_{3} \mathrm{PO}_{4}$ Solid Electrolytes Fabricated by ArF Excimer Laser Deposition J Electrochem Soc 157 A521-A557

Kuwata N, Kawamura J, Toribami K and Sata N (2004) Thinfilm lithium-ion battery with amorphous solid electrolyte fabricated by pulsed laser deposition Electrochem Commun 6 417-421

Kuwata N, Kumar R, Toribami K, Suzuki T, Hattori T and Kawamura J (2006) Thin film lithium ion batteries prepared only by pulsed laser deposition Solid State Ionics 177 $2827-2832$

Lee J M, Kim S H, Tak Y and Yoon Y S (2006) Study on the LLT solid electrolyte thin film with LiPON interlayer intervening between LLT and electrodes Journal of Power Sources 163 173-179

Lee S-H, Liu P, Tracy C and Benson D-K (1999) All Solid State Rocking Chair Lithium Battery on a Flexible Al Substrate Electrochem Solid-state Lett 2 425-427

Lee S J, Baik H K and Lee S M (2003) An all-solid-state thin film battery using LISIPON electrolyte and $\mathrm{Si}-\mathrm{V}$ negative electrode films Electrochem Commun 5 32-35

Li C-L, Sun Q, Jiang G-Y, Fu Z-W and Wang B-M (2008) Electrochemistry and Morphology Evolution of Carbon Micro-net Films for Rechargeable Lithium Ion Batteries $J$ Phys Chem C 112 13782-13788

Li C-L, Liu W-Y and Fu Z-W (2006) Physical and Electrochemical Characterization of $\mathrm{LiCo}_{0.8} \mathrm{M}_{0.2} \mathrm{O}_{2}(\mathrm{M}=\mathrm{Ni}, \mathrm{Zr})$ Cathode Films for All-solid-state Rechargeable Thin-film Lithium Batteries Chin J Chem Phys 19 493-499

Li C-L and Fu Z-W (2007) All-solid-state rechargeable thin film lithium batteries with $\mathrm{Li}_{\mathrm{x}} \mathrm{Mn}_{2} \mathrm{O}_{4}$ and $\mathrm{LixMn}_{2} \mathrm{O}_{4-0.5} \mathrm{ZrO}_{2}$ cathodes Electrochim Acta 52 6155-6164

Li C-L, Zhang B and Fu Z-W (2006) Physical and Electrochemical Characterization of Thin Films of Iron Phosphate and nitride Iron Phosphate for All-Solid-State Batteries $J$ Electrochem Soc 153 E160-E165

Li C-L and Fu Z-W (2008) Nano-sized copper tungstate thin films as positive electrodes for rechargeable Li batteries Electrochem Acta 53 4293-4301

Li C-L, Sun K, Yu L and Fu Z-W (2009) Electrochemical reaction of lithium with orthorhombic bismuth tungstate thin films fabricated by radio-frequency sputtering Electrochim Acta 
55 6-12

Li C-L and Fu Z-W (2008) Electrochemical characterization of amorphous $\mathrm{LiFe}\left(\mathrm{WO}_{4}\right)_{2}$ thin films as positive electrodes for rechargeable lithium batteries Electrochem Acta $\mathbf{5 3}$ 6434-6443

Li D, Ma Z, Xu J, Li Y and Kai X (2014) High temperature property of all-solid-state thin film lithium battery using LiPON electrolyte Materials Letters 134 237-239

Liu Z, Tang Y, Lü X, Ren G and Huang F (2014) Enhanced ionic conductivity of sulfide-based solid electrolyte by incorporating lanthanum sulfide Ceram Int 4015497 15501

Li W, Dahn J R, Wainwright D S (1994) Rechargeable lithium batteries with aqueous electrolytes Science 264 1115-1118

Machida N, Hidekazu Y and Toshihiko S (2004) Chemistry Letters 33 pp. 30-31, 0366-7022

Ma J and Qin Q-Z (2005) Electrochemical performance of nanocrystalline $\mathrm{LiMPO}_{4}$ thin-films prepared by electrostatic spray deposition J Power Sources 148 66-71

Masashi K, Hirokazu M, Kiyoshi K, Yosuke S and Toshihiro Y (2010) Compatibility of $\mathrm{Li}_{7} \mathrm{La}_{3} \mathrm{Zr}_{2} \mathrm{O}_{12}$ solid electrolyte to all-solid-state battery using Li metal anode J Electrochem Soc 157 A1076-A1079

Matsumura T, Nakano K, Kanno N, Hirano A, Imanishi N and Takeda Y (2007) Nickel sulfides as a cathode for all-solidstate ceramic lithium batteries J Power Sources 174632 636

Maqueda O, Sauvage F, Laffont L, Martinez-Sarrion, Mestres L and Baudrin E (2008) Structural, microstructural and transport properties study of lanthanum lithium titanium perovskite thin films grown by Pulsed Laser Deposition Thin Solid Films 516 1651-1655

Meunier G, Dormoy R andLevasseur A (1989) New Positiveelectrode Materials for Lithium Thin Film Secondary Batteries Mater Sci Eng B 319-23

Miyauchi K (1983) Lithium Ion Conductive Thin-Films and Their Electrical Properties Denki Kagaku 51 pp. 211-212, 03669297

Mount E (2003) Principles of Chemical Vapor Deposition (Book) Sci-Tech News 57 pp. 80, 00368059

Mrgudich J N (1960) Conductivity of Silver Iodide Pellets for Solid Electrolyte Batteries J Electrochem Soc 107 475479

Murugan R, Thangadurai V and Weppner W (2007) Fast lithium ion conduction in garnet-type $\mathrm{Li}_{7} \mathrm{La}_{3} \mathrm{Zr}_{2} \mathrm{O}_{12}$ Angew Chem Int Ed 46 7778-7781

Nakazawa H, Sano K and Baba M (2005) Fabrication by using a sputtering method and charge-discharge properties of largesized and thin-filmed lithium ion rechargeable batteries $J$ Power Sources 146 758-761

Nakazawa H, Sano K, Abe T, Baba M and Kumagai N (2007) Charge-discharge characteristics of all-solid-state thinfilmed lithium-ion batteries using amorphous $\mathrm{Nb}_{2} \mathrm{O}_{5}$ negative electrodes J Power Sources 174 838-842

Nakazawa H, Sano K, Baba M and Kumagai N (2015) Stability of Thin-Film Lithium-Ion Rechargeable Batteries Fabricated by Sputtering Method without Heating Journal of Electrochemical Society 162 A392-A397

Nishio Y, Kitaura H, Hayashi A andTatsumisago M (2009) Allsolid-state lithium secondary batteries using nanocomposites of NiS electrode $/ \mathrm{Li}_{2} \mathrm{~S}_{-} \mathrm{P}_{2} \mathrm{~S}_{5}$ electrolyte prepared via mechanochemical reaction $J$ Power Sources 189 629-632

Neudecker B J, Zuhr RA and Bates J B (1999) Lithium silicon tin oxynitride $\left(\mathrm{Li}_{\mathrm{y}} \mathrm{SiTON}\right)$ : high-performance anode in thinfilm lithium-ion batteries for microelectronics $J$ Power Sources 81 27-32

Neudecker N B, Robertson J D and Bates J B (1998) Lithium Manganese Nickel Oxides $\mathrm{Li}_{\mathrm{x}}\left(\mathrm{Mn}_{\mathrm{y}} \mathrm{Ni}_{1 " \mathrm{y}}\right)_{2{ }^{\mathrm{x}}} \mathrm{O}_{2}$ : II. Electrochemical Studies on Thin Film Batteries $J$ Electrochem Soc 145 4160-4168

Neudecker B J, Zuhr RA and Bates J B (1999) Lithium silicon tin oxynitride ( $\left.\mathrm{Li}_{\mathrm{y}} \mathrm{SiTON}\right)$ : High-performance anode in thinfilm lithium-ion batteries for microelectronics $J$ Power Sources 81 27-32

Kamaya N, Homma K, Yamakawa Y, Hirayama M, Kanno R, Yonemura M, Kamiyama T, Hama S, Kato K and Mitsui A (2011) A lithium superionic conductor Nature materials 10 682-686

Kanno R and Murayama M (2001) Lithium ionic conductor thioLISICON the $\mathrm{Li}_{2} \mathrm{~S}-\mathrm{GeS}_{2}-\mathrm{P}_{2} \mathrm{~S}_{5}$ system Journal of the Electrochemical Society 148 A742-A746

Ohta N, Takada K, Osada M, Zhang L Q, Sasaki T and Watanabe M (2005) Solid electrolyte, thio-LISICON, thin film prepared by pulsed laser deposition Journal of Power Sources 146 707-710

Ohtsuka H and J Yamaki (1989) Electrical Characteristics of $\mathrm{Li}_{2} \mathrm{O}-\mathrm{V}_{2} \mathrm{O}_{5}-\mathrm{SiO}_{2}$ Thin-Films Solid State Ionics 35 pp. 201206, 0167-2738

Ohtsuka H (1990) Solid-State Battery with $\mathrm{Li}_{2} \mathrm{O}-\mathrm{V}_{2} \mathrm{O}_{5}-\mathrm{SiO}_{2}$ Solid Electrolyte Thin Film Solid State Ionics 40 pp. 964-966, 0167-2738

Ohtsuka H and Sakurai Y (2001) Characteristics of Li/MoO ${ }_{3 " \mathrm{x}}$ thin film batteries Solid State Ionics 144 59-64 
Ohtsuka H and Yamaki J-I (1989a) Preparation and Electrical Conductivity of $\mathrm{Li}_{2} \mathrm{O}-\mathrm{V}_{2} \mathrm{O}_{5}-\mathrm{SiO}_{2}$ Thin Films Jap Jour of Appl Phys 28 2264-2267

Ohtsuka H and Yamaki J-I (1989b) Electrical characteristics of $\mathrm{Li}_{2} \mathrm{O}-\mathrm{V}_{2} \mathrm{O}_{5}-\mathrm{SiO}_{2}$ thin films Solid State Ionics 35 201-206

Ohtsuka H and Sakurai Y (2001) Characteristics of $\mathrm{Li} / \mathrm{MoO}_{3 " \mathrm{x}}$ thin film batteries Solid State Ionics 144 59-64

Pana G X, Caoa F, Zhanga Y J and Xia X H (2018) Integrated carbon cloth supported $\mathrm{LiFePO}_{4} / \mathrm{N}-\mathrm{C}$ films as highperformance cathode for lithium ion batteries Materials Research Bulletin 98 70-76

Park Y S (1999) All-solid-state lithium thin-film rechargeable battery with lithium manganese oxide Electrochemical and Solid State Letters 2 pp. 58-59, 1099-0062

Park Y S, Lee S H, Lee B I and Joo S-K (1999) All Solid State Lithium Thin Film Rechargeable Battery with Lithium Manganese Oxide Electrochem Solid-state Lett 2 58-59.

Polat B D, Eryilmaz O L, Kele ${ }^{\circ} \mathrm{O}$ and Amine K (2015) Compositionally graded $\mathrm{SiCu}$ thin film anode by magnetron sputtering for lithium ion battery Thin Solid Films $\mathbf{5 9 6}$ 190-197

Polat B D and Keles O (2016) Functionally Graded Si Based Thin Films as Negative Electrodes for Next Generation Lithium Ion Batteries Electrochimica Acta 187 293-299

Rambabu A, Senthilkumar B, Dayamani A, Krupanidhi S B and Prabeer Barpanda (2018) preferentially oriented $\mathrm{SrLi}_{2} \mathrm{Ti}_{6} \mathrm{O}_{14}$ thin film anode for Li-ion microbatteries fabricated by pulsed laser deposition Electrochimica Acta $269212-216$

Ravikumar M K, Suman Rathod, Nandini Jaiswal, Satish Patil and Ashok Shukla (2017) The renaissance in redox flow batteries J Solid State Electrochem 21 2467-2488

Robertson A D, West A R and Ritchie A G (1997) Review of crystalline lithium-ion conductors suitable for high temperature battery applications Solid State Ionics 104 111

Sakurai Y, Sakuda A and Hayashi A (2011) Multivalent ionic conductivity in the series of phosphates $\mathrm{La}_{\mathrm{x}} \mathrm{Yb}_{1 /}$ ${ }_{3 " \mathrm{x}} \mathrm{Zr}_{2}\left(\mathrm{PO}_{4}\right)_{3}$ with NASICON structure Solid State Ionics 182 59-63

Sangryun K, Masaaki H, Sou T and Ryoji K (2013) Epitaxial growth and lithium ion conductivity of lithium-oxide garnet for an all solid-state battery electrolyte Dalton Trans $\mathbf{4 2}$ 13112-13117

Sauvage F, Baudrin E, Morcrette M and Tarascon J-M (2004) Pulsed Laser Deposition and Electrochemical Properties of $\mathrm{LiFePO}_{4}$ Thin Films Electrochem Solid-state Lett 7 A15-
A18

Sauvage F, Baudrin E, Laffont L and Tarascon J M (2007) Origin of electrochemical reactivity enhancement of post-annealed $\mathrm{LiFePO}_{4}$ thin films Preparation of heterosite-type $\mathrm{FePO}_{4}$ Solid State Ionics 178 145-152

Schichtel P, Geiß M, Leichtweiß T, Sann J, Weber D A and Janek J (2017) On the impedance and phase transition of thin film all-solid-state batteries based on the $\mathrm{Li}_{4} \mathrm{Ti}_{5} \mathrm{O}_{12}$ system Journal of Power Sources 360 593-604

Shokoohi F K (1991) Fabrication of Thin-Film LiMn ${ }_{2} \mathrm{O}_{4}$ Cathodes for Rechargeable Microbatteries Applied Physics Letters 59 pp. 1260-1262, 0003-6951

Sivajee G K, Purusottam Reddy B, Hussain M, Mauger A and Julien C M (2016) Influence of Ti and Zr dopants on the electrochemical performance of $\mathrm{LiCoO}_{2}$ film cathodes prepared by rf-magnetron sputtering Materials Science and Engineering B 209 30-36

Souquet J L and Duclot M (2002) Thin film lithium batteries Solid State Ionics 148 pp. 375-379, 0167-2738

Steven D J and James R A (1995) Development and performance of a rechargeable thin-film state microbattery $J$ Power Sources 54 63-67

Stramare S, Thangadurai V and Weppner W (2003) Lithium Lanthanum Titanates: A Review Chemistry of Materials 15 3974-3990

Takada K (2013) Progress and prospective of solid-state lithium batteries Acta Materialia 61 759-770

Thangadurai V and Weppner W (2005) Investigations on electrical conductivity and chemical compatibility between fast lithium ion conducting garnet-like $\mathrm{Li}_{6} \mathrm{BaLa}_{2} \mathrm{Ta}_{2} \mathrm{O}_{12}$ and lithium battery cathodes Jour of Power Sources 142 339344

Thangadurai V and Weppner W (2006) Recent progress in solid oxide and lithium ion conducting electrolytes research Ionics 12 81-92

Tong Y, Xu Z, Liu C, Zhang G, Wang J and Wu Z-G (2014) Magnetic sputtered amorphous $\mathrm{Si} / \mathrm{C}$ multilayer thin films as anode materials for lithium ion batteries Journal of Power Sources 247 78-83

Ueda A, Nagao M, Inoue A, Hayashi A, Seino Y, Ota T and Tatsumisago M (2013) Electrochemical performance of all-solid-state lithium batteries with $\mathrm{Sn}_{4} \mathrm{P}_{3}$ negative electrode J Power Sources 244 597-600

Vereda F, Goldner R B, Haas T E and Zerigian P (2002) Rapidly Grown IBAD LiPON Films with High Li-Ion Conductivity and Electrochemical Stability Electrochemical and SolidState Letters 5 A239-A241 
Wang B, Bates J B, Hart F X, Sales B C, Zuhr R A and Robertson J D (1996) Characterization of Thin Film Rechargeable Lithium Batteries with Lithium Cobalt Oxide Cathodes $J$ Electrochem Soc 143 3203-3213

Wang B, Bates J B, Hart F X, Sales B C, Zuhr R A and Robertson J D (1996) Characterization of Thin Film Rechargeable Lithium Batteries with Lithium Cobalt Oxide Cathodes Journal of the Electrochemical Society 143 3203-3213

Wang Y, Roller J and Maric R (2017) Direct Dry Synthesis of Thin Nanostructured $\mathrm{LiNi}_{0.8} \mathrm{Co}_{0.2} \mathrm{O}_{2}$ Film for Lithium Ion Micro-battery Cathodes Electrochimica Acta 241 510-516

Wang Z, Santhanagopalan D, Zhang W, Wang F, Xin H-L, He K, Li J, Dudney N J and Meng Y S (2016) In situ STEMEELS Observation of Nanoscale Interfacial Phenomena in All-Solid-State Batteries Nano Lett 16 3760-3767

Wen-Yen L, Zhen-Wen F and Qi-Zong Q (2007) A sequential thin-film deposition equipment for in-situ fabricating allsolid-state thin film lithium batteries Thin Solid Films $\mathbf{5 1 5}$ 4045-4048

West W C and Whitacre J F (2005) Long Cycle Life Elevated Temperature Thin-Film Batteries Incorporating $\mathrm{MoO}_{3}$ Cathodes J Electrochem Soc 152 A966-A969

West W-C, Whitacre J F and Ratnakumar B V (2003) Radio Frequency Magnetron-Sputtered $\mathrm{LiCoPO}_{4}$ Cathodes for 4.8 V Thin-Film Batteries $J$ Electrochem Soc 150 A1660A1666

Whitacre J F, West W C, Brandon E and Ratnakumar B V (2001) Crystallographically Oriented Thin-Film Nanocrystalline Cathode Layers Prepared Without Exceeding $300^{\circ} \mathrm{C} \mathrm{J}$ Electrochem Soc 148 A1078-A1084

Whitacre J F, West W C and Ratnakumar B V (2003) A Combinatorial Study of $\mathrm{Li}_{\mathrm{y}} \mathrm{Mn}_{\mathrm{x}} \mathrm{Ni}_{2}$ ${ }_{x} \mathrm{O}_{4}$ Cathode Materials Using Microfabricated Solid-State Electrochemical Cells J Electrochem Soc 150 A1676-A1683

Whitacre J F and West W C (2004) Crystalline $\mathrm{Li}_{3} \mathrm{PO}_{4} / \mathrm{Li}_{4} \mathrm{SiO}_{4}$ solid solutions as an electrolyte for film batteries using sputtered cathode layers Solid State Ionics 175 251-255

Whittingham M S (2004) Lithium batteries and cathode materials Chemical Reviews 104 pp. 4271-4301, 0009-2665

Willmott P R and Huber J R (2000) Pulsed laser vaporization and deposition Rev Mod Phys 72 315-328

Wu X M, Li X H, Wang S W, Wang Z, Zhang Y-H, Xu M F and He Z Q (2003) Preparation and characterization of lithiumion-conductive $\mathrm{Li}_{1.3} \mathrm{Al}_{0.3} \mathrm{Ti}_{1.7}\left(\mathrm{PO}_{4}\right)_{3}$ thin films by the solution deposition Thin Solid Films 425 103-107

Xia H, Wang H.L, Wei X and Li L (2009) Thin film Li electrolytes for all-solid-state micro-batteries Int. J. Surf. Sci. and
Engg.3(1/2), 23-43.

Xie J, Imanishi N, Zhang N, Hirano A, Takeda Y and Yamamoto O (2009) Li-ion diffusion kinetics in $\mathrm{LiFePO}_{4}$ thin film prepared by radio frequency magnetron sputtering Electrochimica Acta 54 4631-4637

Xiea J, Imanishi N, Zhang T, Hirano A, Takeda Y and Yamamoto $\mathrm{O}$ (2010) $\mathrm{n}$ amorphous $\mathrm{LiCo}_{1 / 3} \mathrm{Mn}_{1 / 3} \mathrm{Ni}_{1 / 3} \mathrm{O}_{2}$ thin film deposited on NASICON-type electrolyte for all-solidstate Li-ion batteries Journal of Power Sources 195 57805783

Xu X, Wen Z, Yang X, Zhang J and Gu Z (2006) High lithium ion conductivity glass-ceramics in $\mathrm{Li}_{2} \mathrm{O}-\mathrm{Al}_{2} \mathrm{O}_{3}-\mathrm{TiO}_{2}-\mathrm{P}_{2} \mathrm{O}_{5}$ from nanoscaled glassy powders by mechanical milling Solid State Ionics 177 2611-2615

Yamaki J, Ohtsuka H and Shodai T (1996) Rechargeable lithium thin film cells with inorganic electrolytes Solid State Ionics 86 1279-1284

Yamashita M (1999) Studies on magnetron sputtering assisted by inductively coupled RF plasma for enhanced metal ionization Japanese Journal of Applied Physics Part 1Regular Papers Short Notes \& Review Papers 38 pp. 42914295, 0021-4922.

Yamashita M, Yamanaka H and Wakabayashi H (1996) Thin-film preparation of the $\mathrm{Li} 2 \mathrm{~S}-\mathrm{GeS}_{2}-\mathrm{Ga}_{2} \mathrm{~S}_{3}$ glass system by sputtering Solid State Ionics 89 299-304

Yamashita M, and Yamanaka H (2003) Formation and ionic conductivity of $\mathrm{Li}_{2} \mathrm{~S}-\mathrm{GeS}_{2}-\mathrm{Ga}_{2} \mathrm{~S}_{3}$ glasses and thin films Solid State Ionics 158 151-156

Yang X, Tang Y, Yu M and Qin Q (2000) Pulsed laser deposition of aluminum tris-8-hydroxyquinline thin films Thin Solid Films 358 187-190.

Yoshitake T, Nagamoto T and Nagayam K (2001) Microstructure of $\beta-\mathrm{FeSi}_{2}$ thin films prepared by pulsed laser deposition Thin Solid Films 381 pp. 236-243, 0040-6090

Yoon Y, Park C, Kim C and Shin D (2013) Lattice orientation control of lithium cobalt oxide cathode film for all-solidstate thin film batteries J Power Sources 226 186-190

Yoon Y, Park C, Kim J and Shin D (2013) The mixed former effect in lithium borophosphateoxynitride thin film electrolytes for all-solid-state micro-batteries Electrochimica Acta 111 144-151

Yufit V, Freedman K, Nathan M, Burstein L, Golodnitsky D andPeled E (2004) Thin-film iron sulfide cathodes for lithium and Li-ion/polymer electrolyte microbatteriesElectrochim. Acta50 417-420.

Yu X-H, Bates J B, Jellison G-E and Hart F X (1997) In Situ Scanning Tunneling Microscope Study of the Passivation 
of $\mathrm{Cu}(111)$ Journal of the Electrochemical Society 144 524-532

Zhao S.L, Fu Z. W and Qin Q. Z (2002) A solid-state electrolyte lithium phosphorus oxynitride film prepared by pulsed laser deposition Thin Solid Films 415 108-113

Zheng Q, Zhang X and Shen Y (2015) Construction of hierarchical porous $\mathrm{NiCo}_{2} \mathrm{O}_{4}$ films composed of nanowalls as cathode materials for high-performance supercapacitor Materials Research Bulletin 64 401-404

Zhu J, Feng J-K, Lu L and Zeng K-Y (2012) In situ study of topography, phase and volume changes of titanium dioxide anode in all-solid-state thin film lithium-ion battery by biased scanning probe microscopy J Power Sources 197 224-230. 